PNL-3750

UC-70

\title{
Nuclear-Waste Encapsulation by Metal-Matrix Casting
}

R. G. Nelson

J. F. Nesbitt

S. C. Slate

May 1981

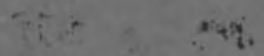

Prepared for the U.S. Department of Energy under Contract DE-AC06-76RLO 1830

Pacific Northwest Laboratory Operated for the U.S. Department of Energy by Battelle Memorial Institute 


\section{NOTICE}

This report was prepared as an account of work sponsored by the United States Government. Neither the United States nor the Department of Energy, nor any of their employees, nor any of their contractors, subcontractors, or their employees. makes any warranty, express or implied, or assumes any legal liability or responsibility for the accuracy, completeness or usefulness of any information, apparatus, product or process disclosed, or represents that its use would not infringe privately owned rights.

The views, opinions and conclusions contained in this report are those of the contractor and do not necessarily represent those of the United States Government or the United States Department of Energy.

PACIFIC NORTHWEST LABORATORY

operated by

BATTELLE

for the

UNITED STATES DEPARTMENT OF ENERGY

Under Contract DE-AC06-76RLO 1830

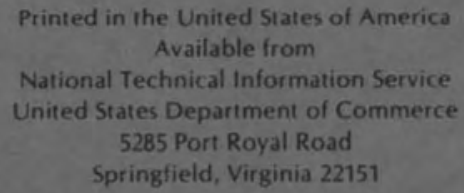

Price: Printed Copy $\$$ $\therefore$ Microfiche $\$ 3.00$

\section{NTIS \\ -Pages Selling Price}

$\begin{array}{ll}001-025 & \$ 4.00 \\ 026-050 & \$ 4.50 \\ 051-075 & \$ 5.25 \\ 076-100 & \$ 6.00 \\ 101-125 & \$ 6.50 \\ 126-150 & \$ 7.25 \\ 151-175 & \$ 8.00 \\ 176-200 & \$ 9.00 \\ 201-225 & \$ 9.25 \\ 226-250 & \$ 9.50 \\ 251-275 & \$ 10.75 \\ 276-300 & \$ 11.00\end{array}$


PNL -3750

UC-70

NUCLEAR-WASTE ENCAPSULATION

BY METAL-MATRIX CASTING

\author{
R. G. Nelson \\ J. F. Nesbitt \\ S. C. Slate
}

May 1981

Prepared for the U.S. Department of Energy under Contract DE-ACO6-76RLO 1830

Pacific Northwest Laboratory

Richland, Washington 99352 
.

.

• 


\section{SUMMARY}

This report describes several encapsulation casting processes that were developed or used at the Pacific Northwest Laboratory to embed simulated high-level wastes of two different forms (glass marbles and ceramic pellets) in metal matrices. Preliminary evaluations of these casting processes and the products are presented.

Demonstrations have shown that 5 - to $10-\mathrm{mm}$-dia glass marbles can be encapsulated on an engineering scale with lead or lead alloys by gravity or vacuum processes. Marbles $212 \mathrm{~mm}$ in dia were successfully encapsulated in a lead alloy on a production scale. Also, 4- to 9-mm-dia ceramic pellets in containers of various sizes were completely penetrated and the individual pellets encased with aluminum-12 wt\% silicon alloy by vacuum processes. Indications are that of the casting processes tested, aluminum 12 wt\% silicon alloy vacuum-cast around ceramic pellets had the highest degree of infiltration or coverage of pellet surfaces. 


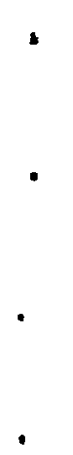




\section{CONTENTS}

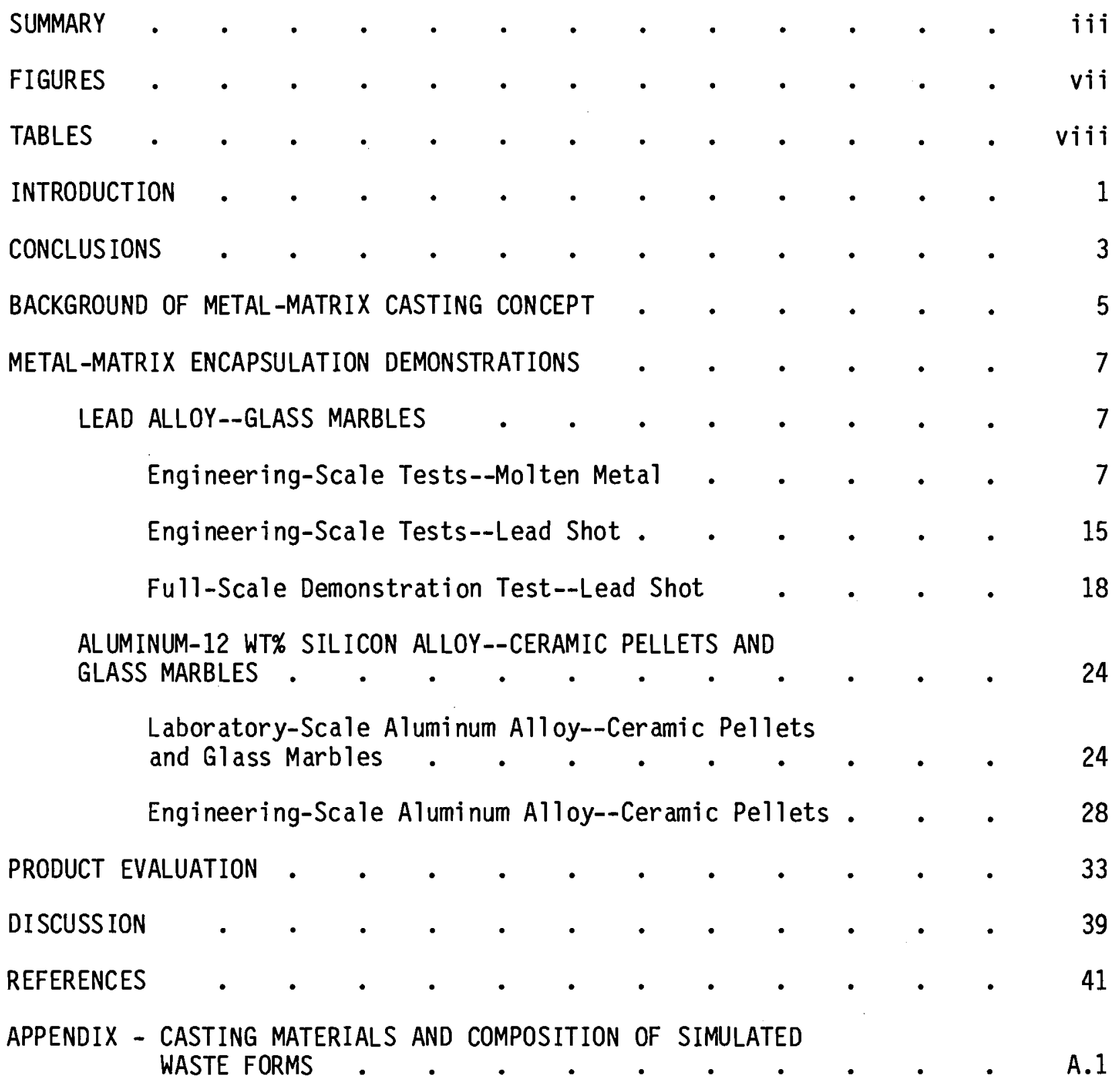


เ

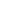

.

.

,

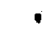




\section{FIGURES}

1 Multibarrier Concept for Isolating High-Level Waste . $\quad$ - 5

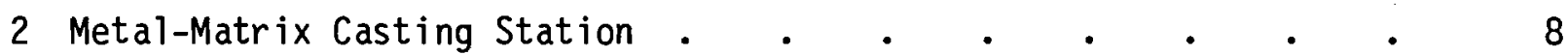

3 Engineering-Scale Metal-Matrix Casting Equipment . $\quad$ • $\quad$ - 9

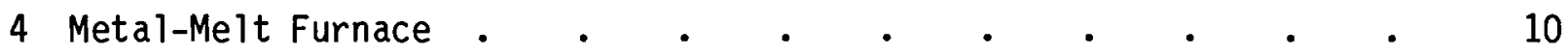

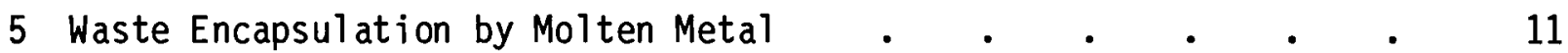

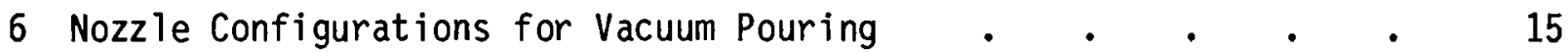

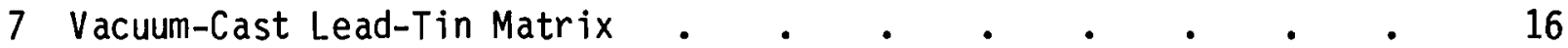

8 Engineering-Scale In-Can Encapsulation of Glass Marbles $\quad$ - $\quad 17$

9 Marbles Gravity-Cast With Lead-Shot Feed $\quad$ - . $\quad$ • . 19

10 Glass Marble Production Schematic . . . . . . . . 20

11 Full-Scale In-Can Encapsulation of Marbles in Lead . . . 22

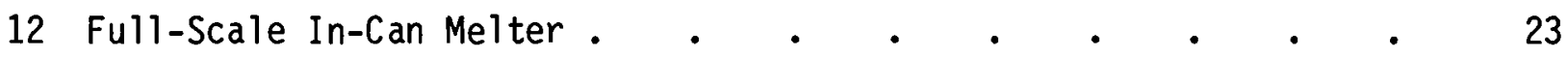

13 Full-Scale Marble-In-Lead Canister . . . . . . . . $\quad 24$

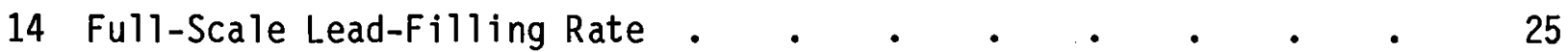

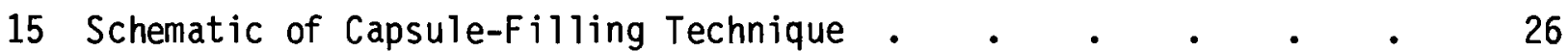

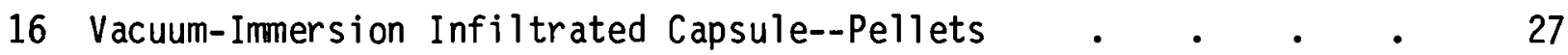

17 Vacuum-Immersion Infiltrated Capsule--Marbles . . . . . 29

18 Vacuum Infiltration of Al-12 Wt\% Si Ceramic Pellets . . . 31

19 Vacuum-Cast Aluminum-Silicon Alloy Matrix--Pellets $\quad$ • • 32

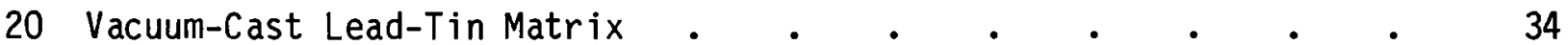

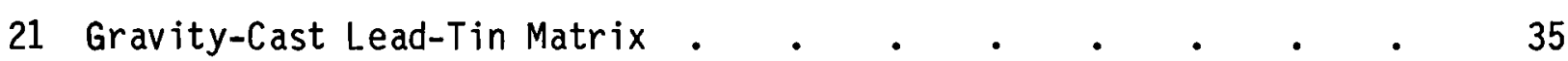

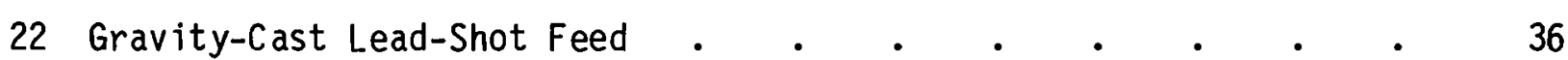

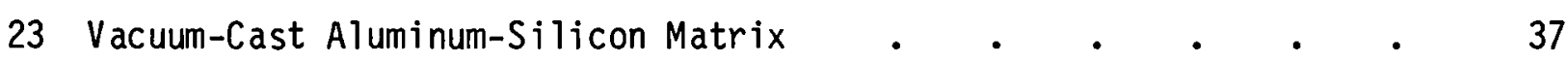

24 Vacuum-Immersion Infiltrated Capsule--Marbles . . . . 38 


\section{TABLES}

1 Summary of Metal-Matrix Casting Demonstration Tests . . . 13

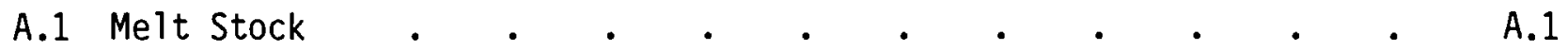

A.2 Composition of Simulated Waste-Glass Marbles . . . . . . A.2

A.3 Simulated-Waste Ceramic Pellets . . . . . . . . . . A.3 


\section{INTRODUCTION}

The safe disposal of nuclear waste is essential for the continued use of nuclear energy in the United States and abroad. Nuclear high-level liquid waste (HLLW) is produced when spent-fuel from nuclear reactors is reprocessed. In this process, the spent fuel assemblies are disassembled, the fuel rods opened, and the fuel dissolved in an acid solution. Various elements are then extracted from the solution, leaving behind a liquid rich in nuclear-fission products.

The solidification of this HLLW and its immobilization are the key elements in most proposed, radioactive-waste management systems. The primary purpose of solidification is to create an inert waste form that minimizes the migration of radionuclides from the waste to the biosphere. The immobilization or encapsulation of the HLLW is designed to assure that the final solidwaste form is compatible with all phases of waste management, including interim storage, transportation and emplacement of the waste form in a repository.

During the past $20 \mathrm{yr}$, numerous waste forms and processes have been proposed for solidifying and/or encapsulating high-level wastes (HLW). Recently, processes applicable to defense wastes were identified and evaluated by Stone, Goforth and Smith (1979), and commercial-waste processes were identified and evaluated by Treat et al. (1980) and E. R. Johnson Associates, Inc. (1980). A number of the waste forms and processes currently under consideration utilize the concept of embedding solid high-level waste forms in a metal matrix that provides multiple layers of isolation.

The specific objective of the metal-matrix casting effort in the Pacific Northwest Laboratory's (PNL) Alternative Waste Forms (AWF) Program is to develop acceptable casting procedures on an engineering scale that can be applied full scale in remotely operated and maintained production processes and facilities. These casting methods are to be compatible with specific waste forms and their integrated processes. 
This report describes the scale-up and development of different casting procedures to demonstrate the feasibility of selected processes for encapsulating simulated HLW glass marbles with lead and lead alloys. Also, procedures to encapsulate simulated wastes in the glass-marble or ceramic-pellet form with an aluminum-12 wt\% silicon alloy are discussed. Demonstrations on laboratory, engineering and full scale were conducted with glass marbles and ceramic pellets, and a full-scale integrated process with marbles was demonstrated. Discussions of these demonstrations, their results and the conclusions based on these tests are presented. 


\section{CONCLUS IONS}

Two basic casting procedures (gravity and vacuum) are feasible for encapsulating and embedding waste forms in metal matrices. Results showed that compared to the gravity process, the vacuum process offered greater penetration of the matrix metal into the interstices of the marble waste-form stack. of both processes tested, the vacuum-casting of aluminum-12 wt\% silicon alloy around ceramic pellets had the highest degree of infiltration or coverage of the pellet surfaces. All of the processes developed or used are adaptable to remote operation and are capable of being scaled up to full production requirements.

Results of laboratory-, engineering-, and full-scale demonstration tests using these processes with glass marbles and ceramic pellets are listed below: Glass Marbles

- Glass marbles 5 to $10 \mathrm{~mm}$ in dia were encased and encapsulated in 20$\mathrm{cm}-\mathrm{dia} \times 80-\mathrm{cm}-1$ ong containers with lead or lead alloy. These engineering-scale tests used gravity and vacuum processes.

- Simulated waste-glass marbles $\sim 12 \mathrm{~mm}$ in dia were successfully encapsulated on a production scale with a lead alloy in a $40-\mathrm{cm}$-dia $x$ 213-cm-1 ong canister.

- Simulated waste-glass marbles 5 to $10 \mathrm{~mm}$ in dia were infiltrated or encapsulated in a $10-\mathrm{cm}-$ dia $\times 15-\mathrm{cm}-1$ ong container with aluminum12 wt\% silicon. This laboratory-scale test used capsule vacuumimmersion techniques that did not melt the marbles. The resulting composite was free of voids.

\section{Ceramic Pellets}

- Ceramic pellets 4 to $9 \mathrm{~mm}$ and 2 to $4 \mathrm{~mm}$ in dia were completely infiltrated or encapsulated with aluminum-12 wt\% silicon alloy on an engineering scale using a vacuum-casting process.

- Ceramic pellets 2 to $4 \mathrm{~mm}$ in dia were completely infiltrated with aluminum-12 wt\% silicon alloy on a laboratory scale using vacuum capsule immersion techniques. 
- Ceramic pellets 4 to $5 \mathrm{~mm}$ in dia could not be gravity-cast with aluminum-12 wt\% silicon alloy using laboratory-scale capsule immersion techniques. 


\section{BACKGROUND OF METAL-MATRIX CASTING CONCEPT}

One of the primary goals of the AWF Program at PNL is the development of waste forms that will provide multiple layers of isolation or protection. Such waste forms would be compatible with the multibarrier concept illustrated in Figure 1. The inner core of the waste form would consist of an inert solid, such as a "supercalcine" pellet or a glass marble (Rusin 1978). This inner core could be coated with additional leach- and oxidation-resistant materials, cast in a metal matrix, and then placed in a metal canister. The resulting composite waste form would exhibit improved thermal stability and mechanical strength, and the added layers would greatly improve leach resistance.

High-level liquid waste can be converted to solids by calcination at temperatures ranging from 500 to $600^{\circ} \mathrm{C}$. The resulting product, or calcine, is thermally stable but is a dispersible powder in the form of particles that range in size from 2 to $500 \mu \mathrm{m}$. Also, the powder has a relatively high solubility in water (Jardine and Steindler 1978). Because of these characteristics--in addition to its poor conductivity and the presence of some residual nitrates--additional processing or treatment of the calcine is required to make a waste form whose properties are suitable for safe handling, transportation and 1 ong-term storage.

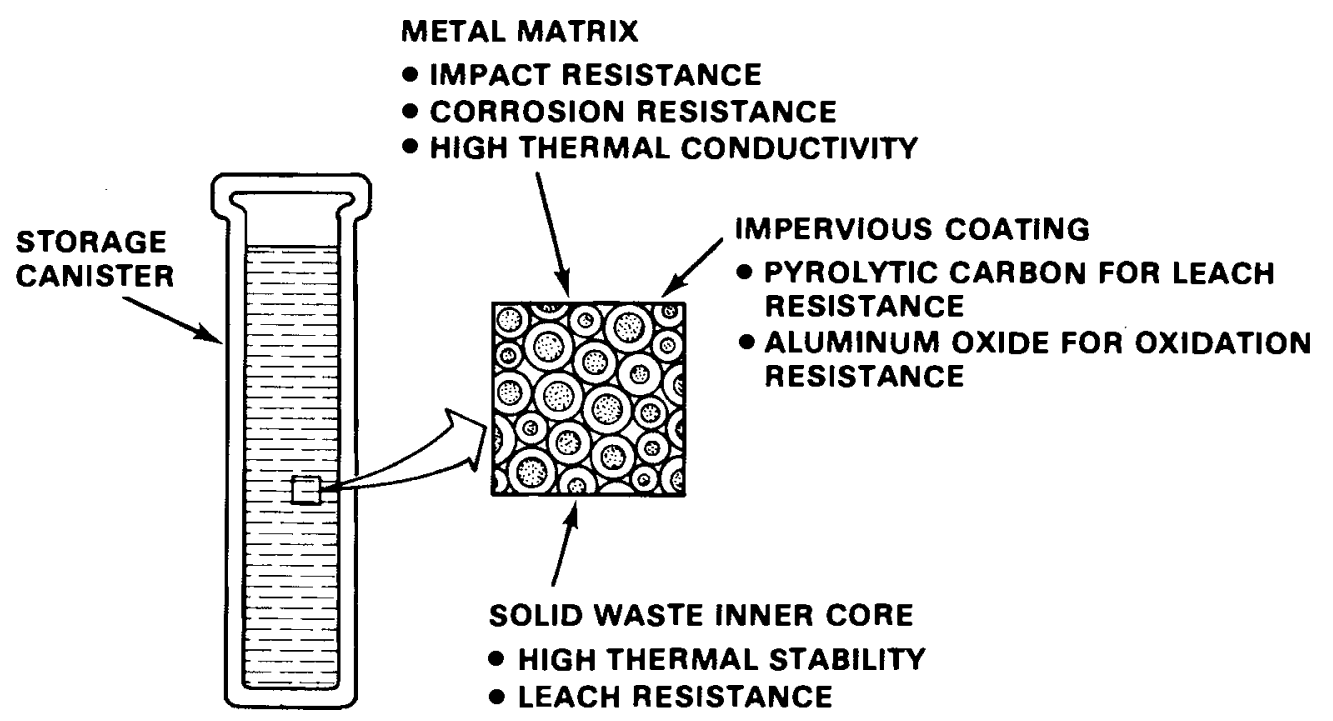

FIGURE 1. Multibarrier Concept for I solating High-Level Waste 
In addition to the problems above, difficulties were experienced in the past (Rhodes 1969) with the incomplete infiltration or encasement of the calcine with a metal matrix because of the small size of the calcine particles. Also, other investigators found that infiltration by casting was incomplete when calcine fines were present in concentrations greater than 10 wt\% (Be11, Cole and Samsel 1976; Berreth, Cole, Samsel and Lewis 1976; VanGeel, Eschrich and Detilleus 1975). However, when larger particles were used to simulate processed calcine waste, successful infiltration was achieved (Sump 1976a and b; Sump and Begej 1976).

At PNL in 1976, laboratory-scale castings $(1.3$ to $3.2 \mathrm{~cm}$ in dia by 1.3 to $3.2 \mathrm{~cm}$ long) of matrix materials (lead, lead-tin, aluminum-silicon, and stainless steel or copper) containing either glass marbles or ceramic pellets were made and evaluated (Rusin et al. 1979). The 5 - to 12 -mm-dia borosilicate glass marbles are made from calcine and suitable glass frits (Treat et al. 1980). The 4- to 9-mm-dia ceramic pellets are made by adding soluble compounds of aluminum, calcium, silicon and strontium to the HLLW before calcination. After calcination, the calcine is pelletized and sintered to form hard, dense, spherical ceramic pellets. This final material is referred to as "supercalcine" (McCarthy 1977; Treat et a1. 1980). Researchers at PNL also made and evaluated 1-L-volume, laboratory-scale, multibarrier waste forms of simulated waste-glass marbles and coated and uncoated ceramic pellets (Rusin et al. 1978).

The purpose of the demonstration discussed here is to identify the feasibility of encapsulating HLW borosilicate glass marbles and "supercalcine" ceramic pellets cast in a metal matrix on a production basis. 


\section{METAL-MATRIX ENCAPSULATION DEMONSTRATIONS}

Many demonstrations have been conducted on metal-matrix casting techniques at PNL in the last $2 \mathrm{yr}$. These have used simulated HLW glass marbles and ceramic pellets and two basic alloys as matrix materials--lead and aluminum12 wt\% silicon. A range of waste-form sizes has been used in laboratory-, engineering- and full-scale tests.

\section{LEAD ALLOY--GLASS MARBLES}

A series of tests used commercial and/or simulated waste-glass marbles and lead alloys. These alloys were used because the softening temperature of borosilicate glass ranges between 500 and $550^{\circ} \mathrm{C}$ and almost all other candidate alloys melt above this temperature. The first tests were on an engineering scale and included molten-metal casting and lead-shot casting. Subsequently, a full-scale test was performed using lead-shot casting. These tests and their results are described below.

\section{Engineering-Scale Tests--Molten Metal}

Figure 2 is a concept of a metal-matrix casting station. The canister has an inner container that retains the waste particles. The container is positioned to allow a gap between the walls and the bottom of the canister, and has a screened bottom and a covered screened vent on the top. Matrix metal is poured into the top of the canister and is deflected to the annulus between the container and the canister by the deflector plate. The metal flows down the annulus, across the bottom of the canister, and up through the bottom of the container into the waste-form particles, forcing air out the upper screened vent. This concept also provides for an optional vacuumassisted vent system.

The molten-metal-matrix casting demonstration equipment is shown in Figure 3. This equipment consists of a furnace to melt the metal, a canister assembly, and a water-cooled canister stool. The casting furnace, schematically shown in Figure 4 , is a $30-\mathrm{kW}$, resistance-wound, bottom-pour furnace. The furnace has a batch capacity of $45 \mathrm{~kg}$ of aluminum or $180 \mathrm{~kg}$ of lead. 


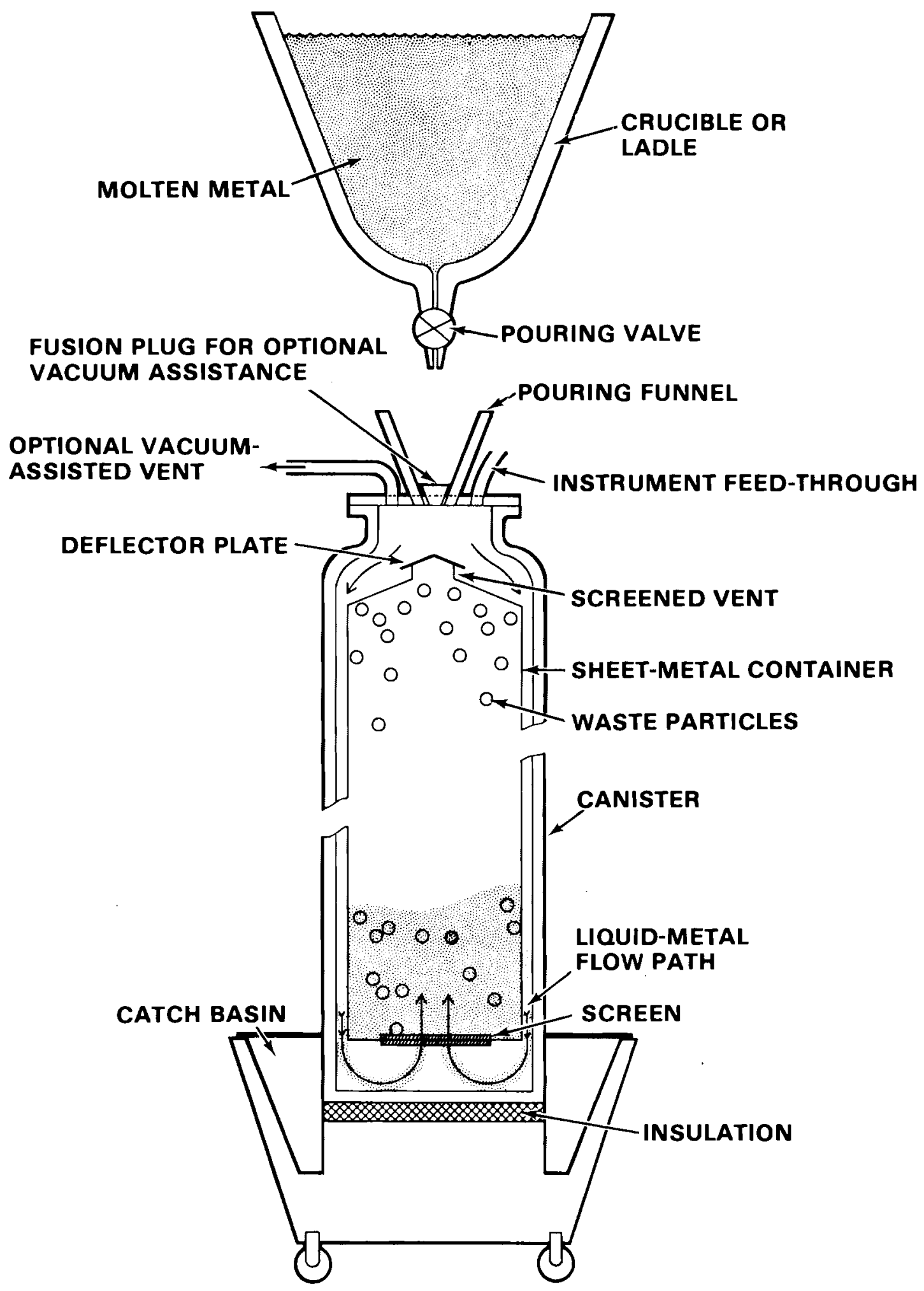

FIGURE 2. Metal-Matrix Casting Station 


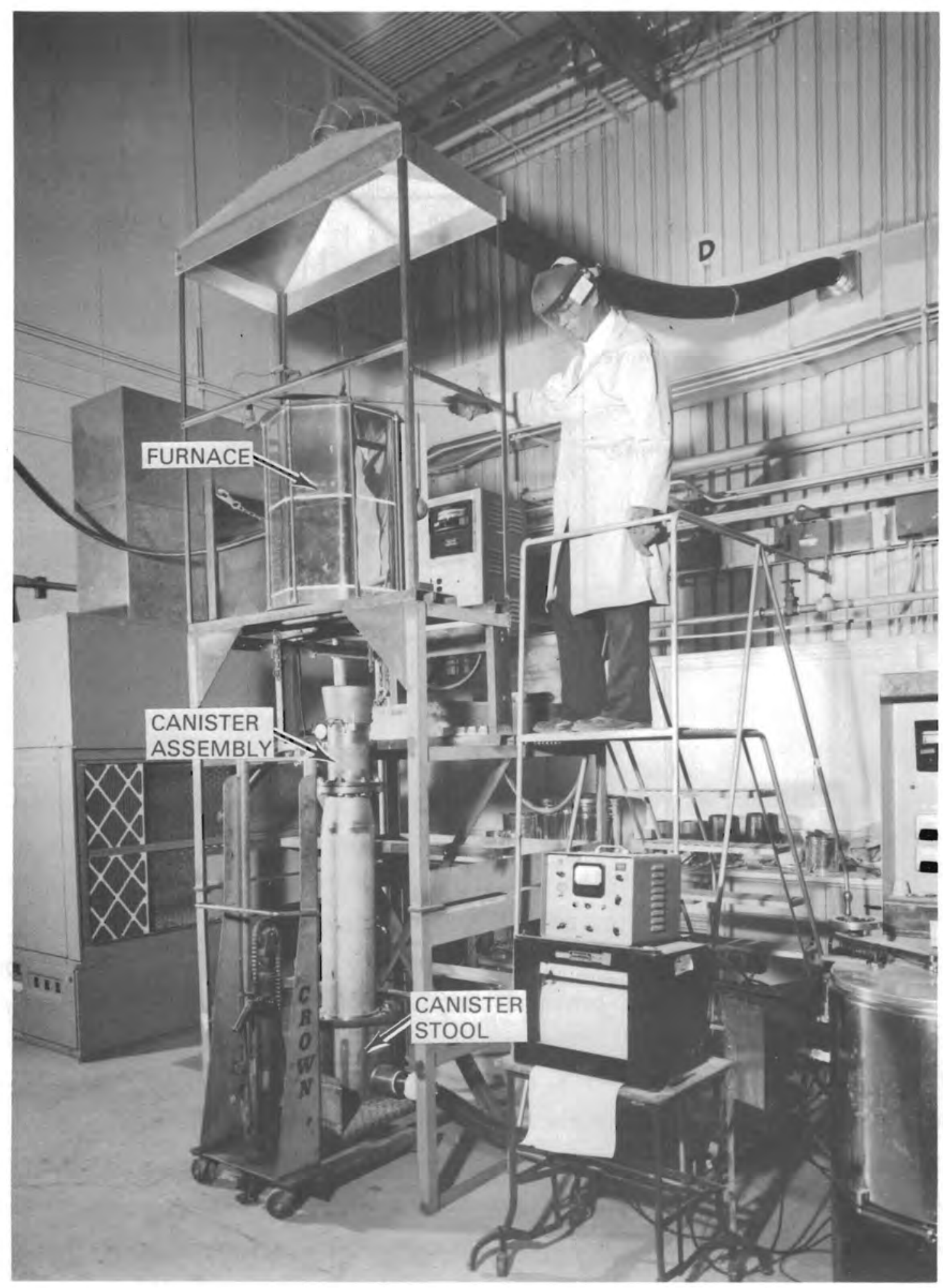

FIGURE 3. Engineering-Scale Meta1-Matrix Casting Equipment 


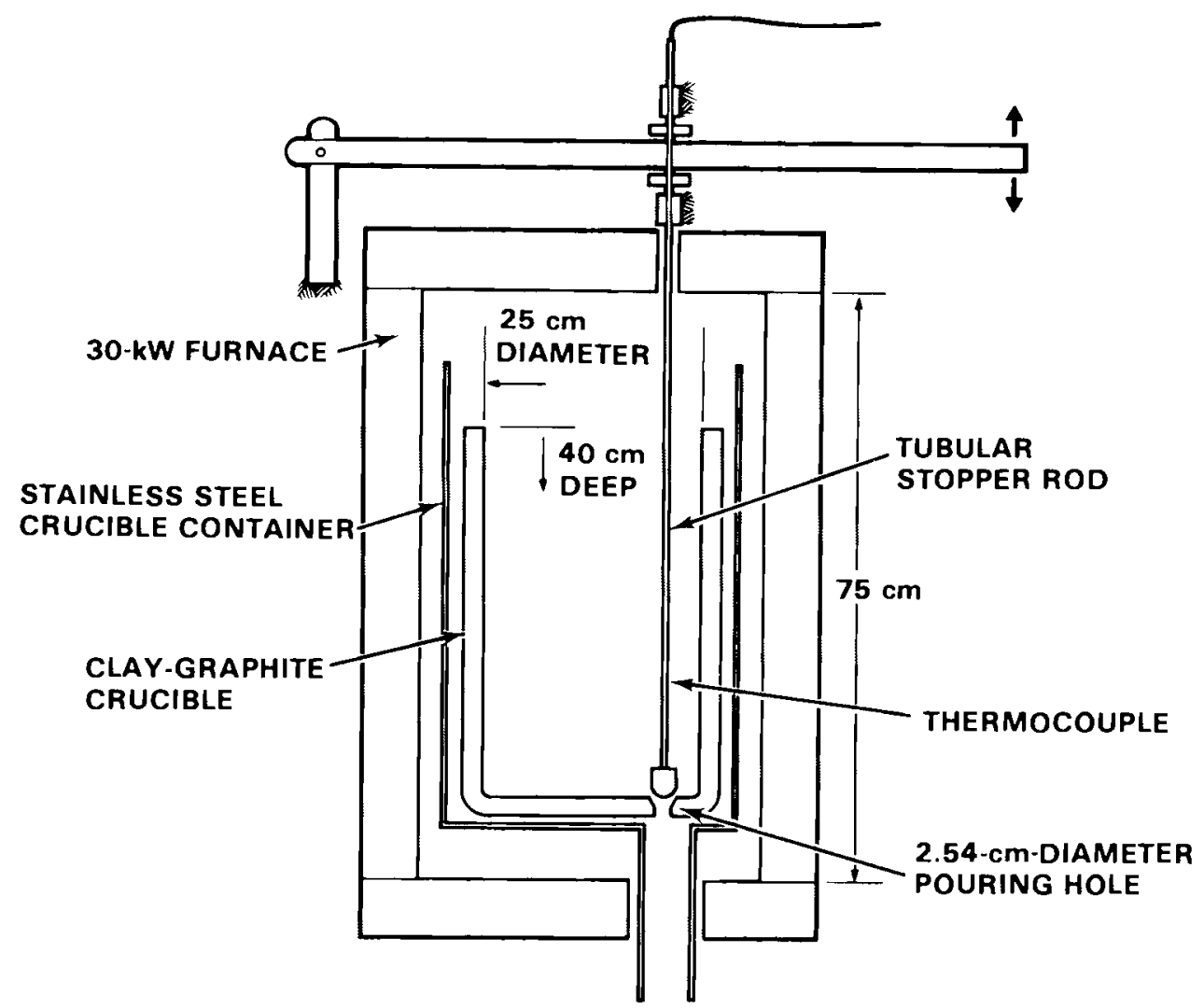

FIGURE 4. Metal-Melt Furnace

The canister assembly and water-cooling stool are shown in Figure 5 . The canister is a Schedule 10 stainless steel pipe with an annulus between the inner waste container and the canister wall. To provide effective seals in a test setup that could be assembled and disassembled efficiently, flanged assemblies with soft copper gaskets were used. The water-cooling stool supports the canister assembly and contains nozzles that spray water directly onto the lower end of the canister. The vacuum-pouring funnel (Figure 5) is equipped with a fusion disk that allows the canister to be evacuated prior to metalmatrix pouring. Pouring of the heated matrix-metal melts the fusion disk, and by keeping the funnel full during pouring, a full dynamic vacuum can be maintained throughout the pour. The vacuum for this test setup was provided from a nearby vacuum-induction melting system having a volume of about $6 \mathrm{~m}^{3}$. 


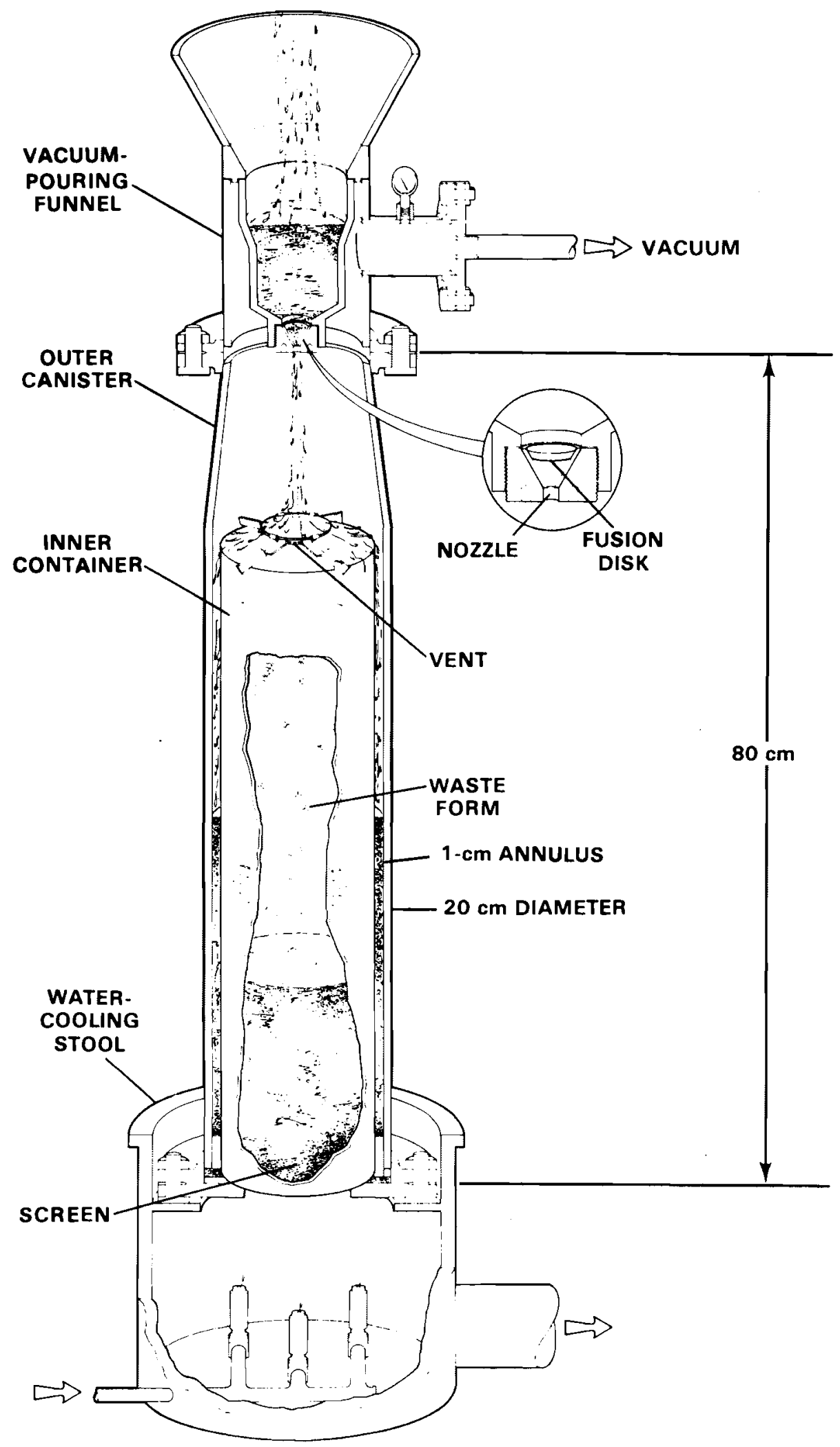

FIGURE 5. Waste Encapsulation by Molten Metal 
Test runs for canister heatup times showed that 10 to $12 \mathrm{~h}$ were required to bring a canister loaded with simulated waste-glass marbles to the $400^{\circ} \mathrm{C}$ temperature felt to be required for adequate infiltration of the lead or lead alloy. A sumary of these tests is given in Table 1.

The first successful test was Number 4. It consisted of a gravity infiltration of $35 \mathrm{~kg}$ of glass marbles with $182 \mathrm{~kg}$ of lead. (The composition of the glass marbles is noted in the Appendix.) Canister preheat and metal-pouring temperatures were $400^{\circ} \mathrm{C}$.

Heat Number 5 was a test run to check the operation of the vacuum-pouring funnel. The funnel was placed on an empty canister with a special container inside to catch the molten metal and thus permit future use of the canister. The nozzle configuration for lead-alloy pouring shown in Figure $6 \mathrm{~A}$ was used on this lead-10 wt\% tin, 66-kg heat. A full vacuum was maintained throughout the pour that took only $27 \mathrm{~s}$.

Heat Numbers 6 (vacuum) (Figure 7) and 7 (gravity) were the demonstration pours for the waste-glass marbles and $\mathrm{Pb}-10$ wt\% Sn matrix-alloy combinations. These heats were performed using the procedures developed in Heat Numbers 5 (vacuum) and 4 (gravity) and listed below.

\section{Engineering-Scale Casting Procedure}

1. Load inner container with waste-form particles.

2. Crimp deflector plate in place.

3. Assemble outer canister over container and attach lower flange.

4. Insert into preheat furnace.

5. Melt matrix alloy and bring to pouring temperature.

6. Remove canister assembly from preheat furnace.

7. Attach pouring funnel with nozzle and fusion disk in place. (a)

8. Place canister on cooling stool.

9. Position canister and cooling stool under pouring hole of casting furnace.

10. Attach vacuum line. (a)

11. Open vacuum valve. (a)

(a) For vacuum pouring only. 


\section{TABLE 1. Summary of Metal-Matrix Casting Demonstration Tests}

\begin{tabular}{|c|c|c|c|c|c|}
\hline $\begin{array}{l}\text { Test or } \\
\text { Heat } \\
\text { Number }\end{array}$ & $\begin{array}{l}\text { Matrix } \\
\text { Alloy } \\
\end{array}$ & Waste Form & $\begin{array}{l}\text { Pour } \\
\text { Temp., } \\
\text { oc } \\
\end{array}$ & $\begin{array}{l}\text { Preheat } \\
\text { Temp., o } \mathrm{C}\end{array}$ & Type of Pour \\
\hline 1 & $\mathrm{~Pb}, 46 \mathrm{~kg}$ & None & 400 & None & Gravity \\
\hline 2 & $\mathrm{~Pb}, 155 \mathrm{~kg}$ & $\begin{array}{l}\text { Mixture of waste- } \\
\text { glass marbles and } \\
\text { commercial l ime } \\
\text { glass, } 34 \mathrm{~kg}\end{array}$ & 416 & 407 & Gravity \\
\hline 3 & $\mathrm{~Pb}$ & $\begin{array}{l}\text { Waste-glass marbles, } \\
35 \mathrm{~kg}\end{array}$ & & & \\
\hline 4 & $\mathrm{~Pb}, 182 \mathrm{~kg}$ & $\begin{array}{l}\text { Waste-glass marbles, } \\
35 \mathrm{~kg}\end{array}$ & 400 & 400 & Gravity \\
\hline 5 & $\begin{array}{l}\mathrm{Pb} 10 \mathrm{wt} \% \mathrm{Sn} \text {, } \\
66 \mathrm{~kg}\end{array}$ & None & 400 & None & Vacuum \\
\hline 6 & $\begin{array}{l}\mathrm{Pb} 10 \mathrm{wt \%} \mathrm{Sn}, \\
178 \mathrm{~kg}\end{array}$ & $\begin{array}{l}\text { Waste-glass marbles, } \\
35 \mathrm{~kg}\end{array}$ & 400 & 400 & Vacuum \\
\hline$\vec{\omega}$ & $\begin{array}{l}\mathrm{Pb}-10 \mathrm{wt \%} \mathrm{Sn}, \\
186 \mathrm{~kg}\end{array}$ & $\begin{array}{l}\text { Waste-glass marbles, } \\
34 \mathrm{~kg}\end{array}$ & 400 & 400 & Gravity \\
\hline 8 & $\begin{array}{l}\text { Al-12 wt\% Si, } \\
27 \mathrm{~kg}\end{array}$ & $\begin{array}{l}\text { Ceramic pellets, } 4 \mathrm{~kg} \text {; } \\
\text { waste-glass marbles, } \\
1.5 \mathrm{~kg}\end{array}$ & 700 & $\begin{array}{l}700 \text { for ceramic } \\
\text { pellets, } 400 \\
\text { for glass mar- } \\
\text { bles }\end{array}$ & $\begin{array}{l}\text { Immersed capsules } \\
\text { Filled by grav- } \\
\text { ity and vacuum }\end{array}$ \\
\hline 9 & $\begin{array}{l}\text { A } 1-12 \text { wt\% } \mathrm{Si} \text {, } \\
42 \mathrm{~kg}\end{array}$ & $\begin{array}{l}\text { Ceramic pellets, } 2 \text { to } \\
5 \mathrm{~mm} \mathrm{dia}, 22 \mathrm{~kg}\end{array}$ & 700 & 700 & Vacuum \\
\hline 10 & $\begin{array}{l}\text { Al }-12 \text { wt\% Si, } \\
42 \mathrm{~kg}\end{array}$ & $\begin{array}{l}\text { Canister loaded same } \\
\text { ds that in Heat No. } 9\end{array}$ & 700 & 700 & Vacuum \\
\hline 11 & $\begin{array}{l}\mathrm{A} 1-12 \text { wt\% } \mathrm{Si}, \\
9 \mathrm{~kg}\end{array}$ & None & 700 & 500 & Vacuum \\
\hline 12 & $\begin{array}{l}\mathrm{Al}-12 \text { wt\% } \mathrm{Si} \text {, } \\
8 \mathrm{~kg}\end{array}$ & None & 700 & 500 & Vacuum \\
\hline
\end{tabular}

\section{Remarks
Furnace checkout made and air sampling conducted for lead
fumes. \\ Flotation hold-down clips gave way. Inner can floated up} out of open canister, causing a molten-metal spill.

Due to leaky pouring valve, test was scrubbed. Loaded canister reusable.

Excellent heat. Very little splashing during pour.

Test pour for vacuum funnel. Sixty lead-40 tin fusion disk $7.1 \mathrm{~mm}(0.28 \mathrm{in.})$ thick; $9.5-\mathrm{mm}\left(0.375-\right.$ in. $_{\text {. }}$-dia nozzle; 27 $s$ pour. Full vacuum and valve wide open all the way.

Fusion disk and nozzle as above. Fifty-five-second pour; full vacuum all the way; used insulating blanket on upper $15 \mathrm{~cm}$ of canister.

Fifty-eight-second pour. Used insulating blanket on upper portion of canister.

Gravity-filled one capsule containing 4- to 5-mm-dia ceramic pellets with an unidentified foreign coating. Vacuumlets. Yacuum-filled one capsule containing 5- to 10-mmdia glass marbles.

Pour failed to penetrate 3-mm (0.125-in.)-thick 6061 aluminum fusion disk because vacuum pouring funnel was not preheated.

Preheated canister with pouring funnel attached. No fusion disk used. Heat failed because vacuum sucked metal into upper part of canister and the vacuum line. Very little matrix metal infiltration of the pellets.

Preheated canister with pouring funnel attached. Small 15cm (6-in.)-dia test. Canister with 3-mm (0.125-in.)-thick Al-12 wtx si a loy fusion disk and $11-m$ (0.438-in.) -dia

Repeat of Heat Number 11. Good results. Matrix metal poured through Al-12 wtz si fusion disk. Eleven millimeter $\left(0.438-\right.$ in. $_{\text {. }}$-dia nozzle was too large. Periodically lost vacuum during pour. 
TABLE 1. (contd)

\begin{tabular}{|c|c|c|c|c|c|}
\hline $\begin{array}{l}\text { Test or } \\
\text { Heat } \\
\text { Number }\end{array}$ & $\begin{array}{l}\text { Matrix } \\
\text { Alloy }\end{array}$ & Waste Form & $\begin{array}{l}\text { Pour } \\
\text { Temp., } \\
\text { OC } \\
\end{array}$ & $\begin{array}{l}\text { Preheat } \\
\text { Temp. }{ }^{\circ} \mathrm{C}\end{array}$ & Type of Pour \\
\hline 13 & $\begin{array}{l}\text { Al-12 wt\% Si, } \\
11 \mathrm{~kg}\end{array}$ & $\begin{array}{l}\text { Ceramic pellets, } 2 \text { to } \\
5 \mathrm{~mm} \text { dia, } 2.2 \mathrm{~kg}\end{array}$ & 730 & 500 & Vacuum \\
\hline 14 & $\begin{array}{l}\mathrm{A} 1-12 \text { wt\% Si, } \\
45 \mathrm{~kg}\end{array}$ & $\begin{array}{l}\text { Ceramic pellets, } 4 \\
\text { to } 9 \mathrm{~mm} \text { dia, } 34 \mathrm{~kg}\end{array}$ & 730 & 500 & Vacuum \\
\hline 15 & $\begin{array}{l}\mathrm{Pb}-3 \text { wt\% So, } \\
8 \mathrm{~mm} \text { dia, } \\
175 \mathrm{~kg}\end{array}$ & $\begin{array}{l}\text { Simulated waste-glass } \\
\text { marbles, } 35 \mathrm{~kg}\end{array}$ & 400 & 400 & Gravity \\
\hline 16 & $\begin{array}{l}\mathrm{Pb}-3 \mathrm{wt} \% \mathrm{Sb} \\
179 \mathrm{~kg}\end{array}$ & $\begin{array}{l}\text { Waste-glass marble, } \\
35 \mathrm{~kg}\end{array}$ & 450 & 450 & Gravity \\
\hline 17 & $\begin{array}{l}\text { Pb-2 wt\% So, } \\
3.3 \mathrm{~mm} \text { dia, } \\
1429 \mathrm{~kg}\end{array}$ & $\begin{array}{l}\text { SRL TOS calcine and } \\
211 \text { frit, } 310 \mathrm{~kg}\end{array}$ & $\begin{array}{l}400- \\
450\end{array}$ & 450 & $\ldots$ \\
\hline
\end{tabular}
Small test canister with Al-12 wt\% Si fusion disk and 9.5- mm (0.375-in.)-dia nozzle. Nozzle diameter too large since some vacuum breaks occurred during the pour. Excellent results. Full infiltration of the waste particles.

Full-size canister with Al-12 wt\% Si, fusion disk and 8.7Imm (0.344-in.)-dia nozzle. Thirty-seven-second por Vacuum all the way with no vacuum breaks. Excellent results with full infiltration.

Inner container hold-down broke and container floated up in canister. Average shot introduction rate $75 \mathrm{~kg} / \mathrm{h}$.

Successful demonstration. Average shot introduction rate $94 \mathrm{~kg} / \mathrm{h}$.

Ful1-production-scale demonstration. Average shot introduction rate $455 \mathrm{~kg} / \mathrm{h}$. 


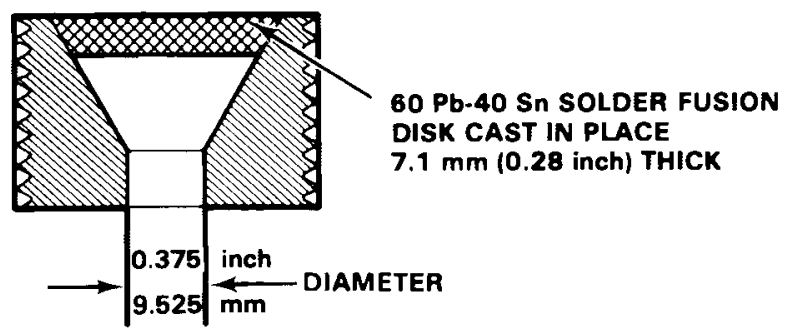

a) FOR LEAD-ALLOY VACUUM POURING

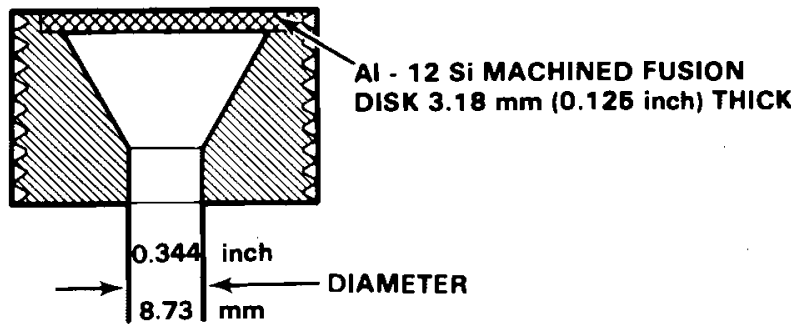

b) FOR ALUMINUM-ALLOY POURING

FIGURE 6. Nozzle Configurations for Vacuum Pouring

12. Attach water supply and drain lines.

13. Pour metal.

14. Open water-cooling valve.

15. Add insulating blanket to upper portion of canister.

(a) For vacuum pouring only.

\section{Engineering-Scale Tests--Lead Shot}

Tests were performed to demonstrate the feasibility of melting the metal matrix in the HLW-process primary storage canister (i.e., the technique of In-Can Encapsulation or ICE). ICE encapsulation would eliminate the handling of molten metal in a remote-process ce11. In the ICE technique, the metal matrix is slowly added to the canister in the form of particles (shot) while the canister and its inner container, loaded with a solid waste form, are in a preheat furnace. Such a test setup is depicted in Figure 8. 


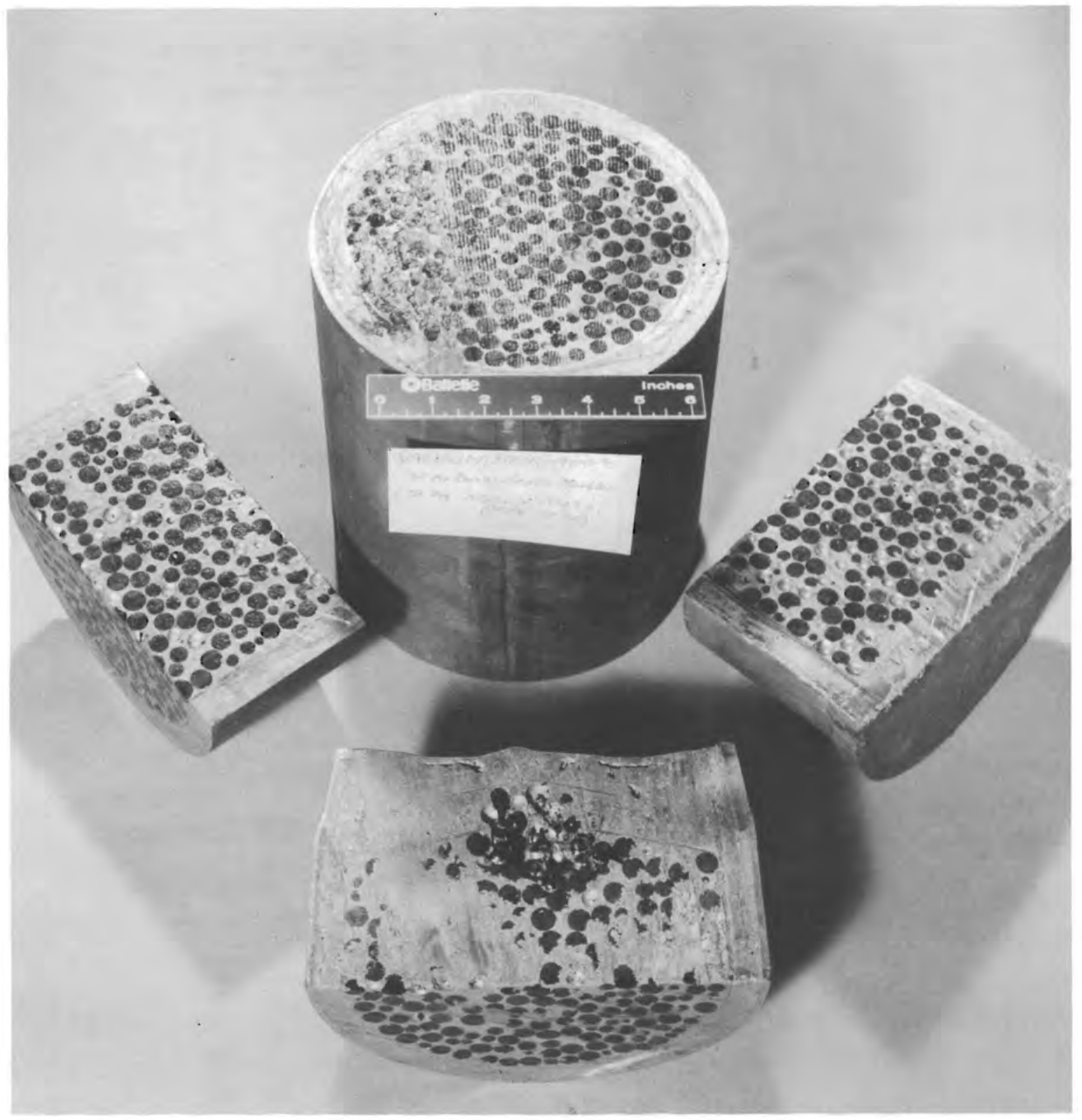

Waste Form: 35 kg Simulated Waste-Glass Marbles Matrix: $178 \mathrm{~kg}$ Lead-10 wt\%-Tin Alloy Heat Number: 6

FIGURE 7. Vacuum-Cast Lead-Tin Matrix 


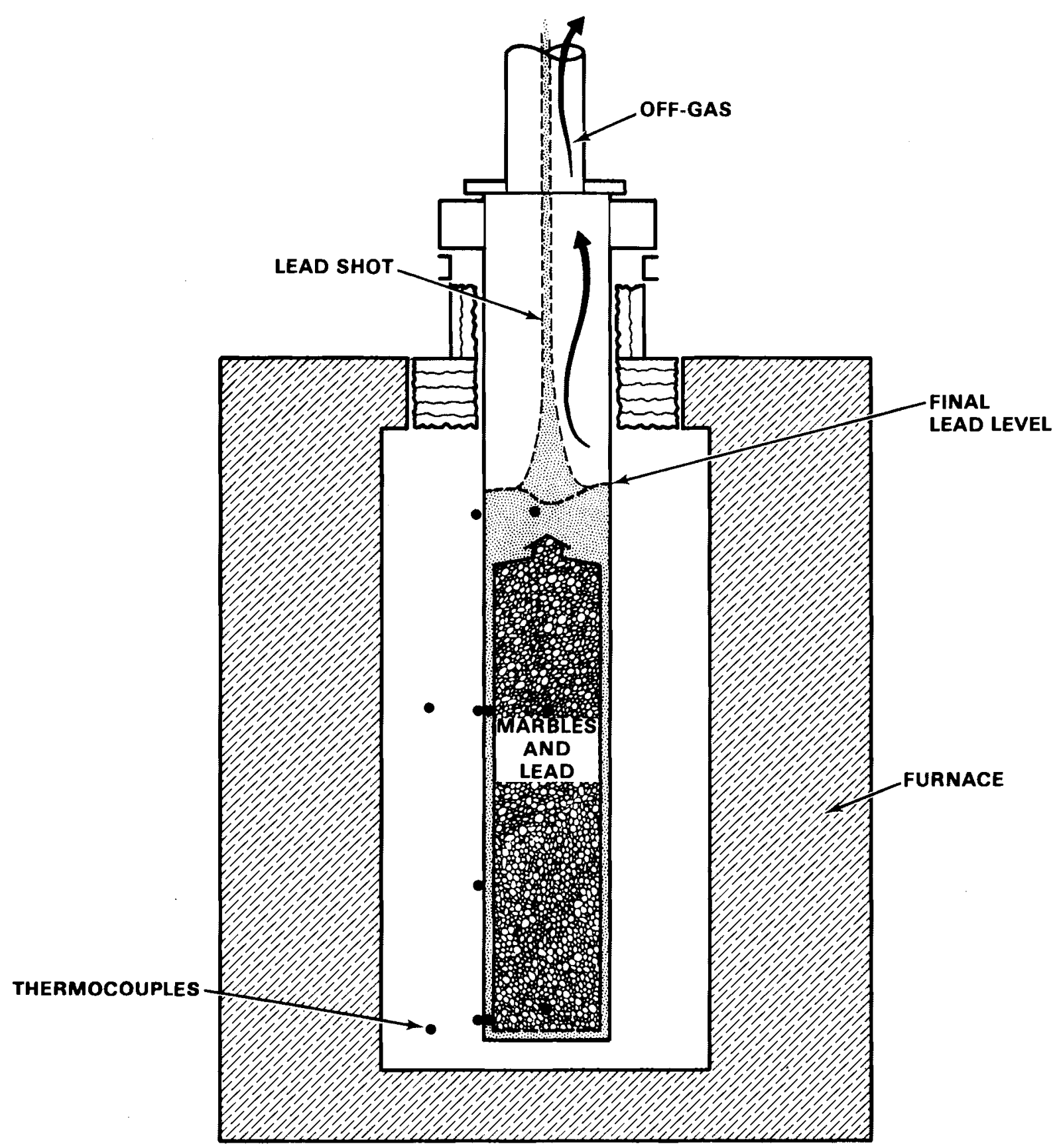

FIGURE 8. Engineering-Scale In-Can Encapsulation of Glass Marbles

Inner containers identical to those used for the previous engineeringscale tests were used. These containers were filled with waste-glass marbles $12 \mathrm{~mm}$ in dia. The filled container was inserted in an open-top 20-cm canister having a length compatible with the existing pilot-scale In-Can Melter 
(ICM). The first ICE test is summarized as Heat Number 15 in Table 1. The test assembly was instrumented as shown in Figure 8.

While a slight vacuum was held on the system $\left(22.5 \mathrm{~cm} \mathrm{H}_{2} \mathrm{O}\right)$, the test setup was preheated to bring the temperature of the marbles to $400^{\circ} \mathrm{C}$. Initially, $34 \mathrm{~kg}$ (75 lb) of 8-mm-dia lead-antimony shot were poured in. Then, after a 15 -min hold to assure that all internal temperatures were above $400^{\circ} \mathrm{C}$, $11.34 \mathrm{~kg}$ of lead shot were introduced about every $10 \mathrm{~min}$. During the pouring of Bag Number 7 of shot $(68$ to $79 \mathrm{~kg}$ ), one of the lower thermocouples oscillated $\sim 10^{\circ} \mathrm{C}$ and then dropped $\sim 20^{\circ} \mathrm{C}$. Later, it was found that the inner container had broken loose from its hold-downs and had floated up about $20 \mathrm{~cm}$. After 15 bags $(170 \mathrm{~kg}$ ) of lead shot had been poured in, the test setup was held at temperature for $30 \mathrm{~min}$ and then disconnected. The canister was removed from the furnace and its upper portion insulated to simulate zone cooling. Then the bottom $10 \mathrm{~cm}$. of the canister was placed in flowing water for a period of $\sim 3 \mathrm{~h}$.

Because the inner container in this first test had broken loose from its original position, a second test was performed. This test, identified as Heat Number 16 in Table 1, followed the same procedure, except the assembly was preheated to $450^{\circ} \mathrm{C}$, which took $\sim 11 \mathrm{~h}$. Two-millimeter-diameter lead-antimony shot was used, and the marble container was welded to the canister to assure that it would stay in place. After $34 \mathrm{~kg}$ of lead shot had been poured in, and after a 15-min hold to assure temperature, an additional $136 \mathrm{~kg}$ of lead shot was inserted in $11.34 \mathrm{~kg}$ batches in the next 90 min. A total of $179 \mathrm{~kg}$ of shot was used. As indicated in Figure 9, the metal matrix fully infiltrated the stack of marbles.

\section{Ful1-Scale Demonstration Test--Lead Shot}

The purpose of this test setup and demonstration was to show the feasibility of in-can encapsulation of marbles in a lead matrix on a scale that would be required in a production process.

In the ICE technique, the glass for the marbles is melted in the Advanced Glass Forms Melter (AGFM) (Dierks 1980), and the molten glass is poured continuously into a marble-making machine (Platt and Powell 1980). Acceptable 


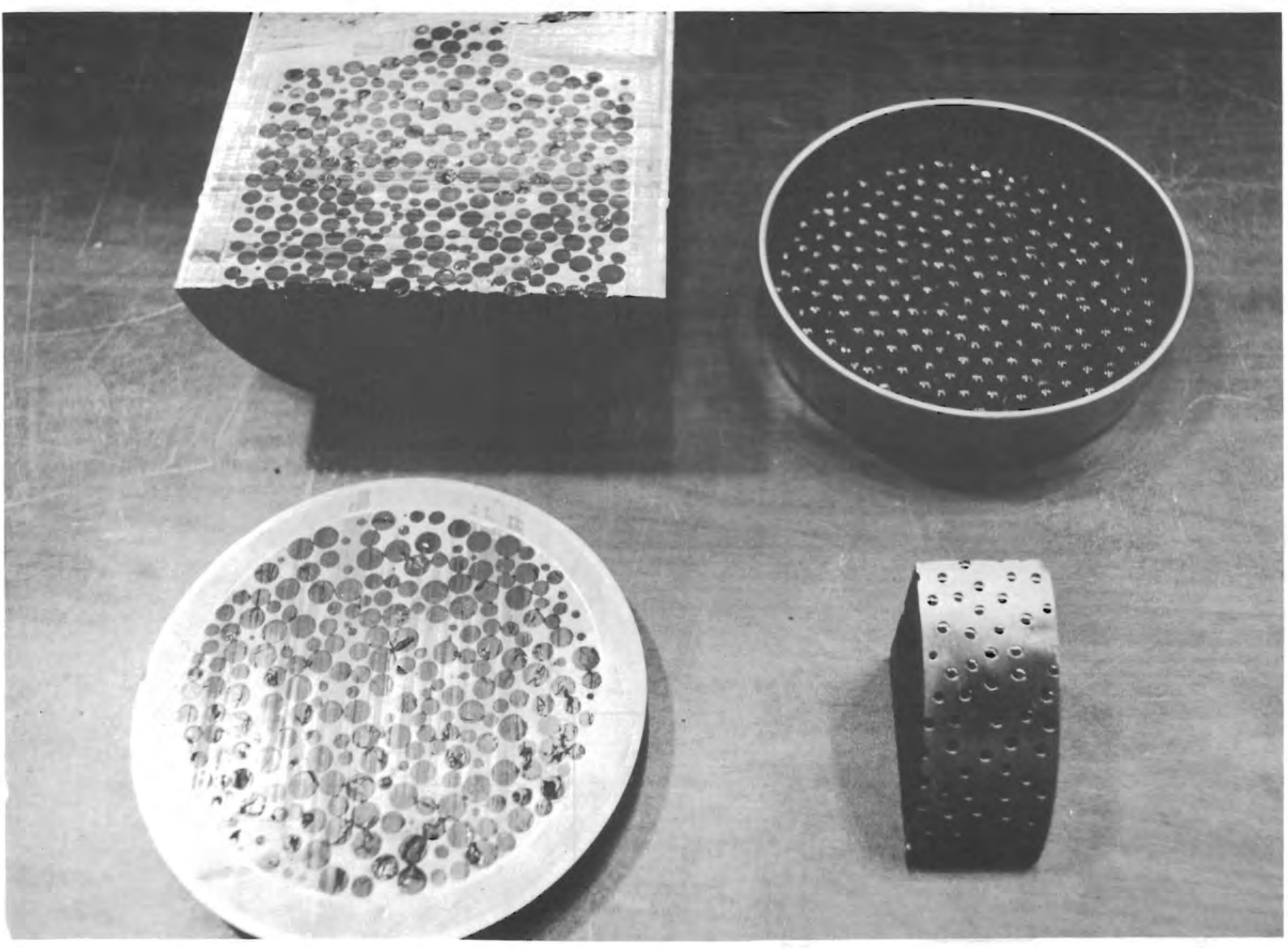

FIGURE 9. Marbles Gravity-Cast With Lead-Shot Feed 
marbles are fed to a basket or container inside a canister. A schematic of this process is shown in Figure 10.

In the full-scale ICE demonstration test, the marble-filled canister was $\mathrm{placed}$ in a furnace which heated the marbles to $\sim 450^{\circ} \mathrm{C}$. (Heating of the

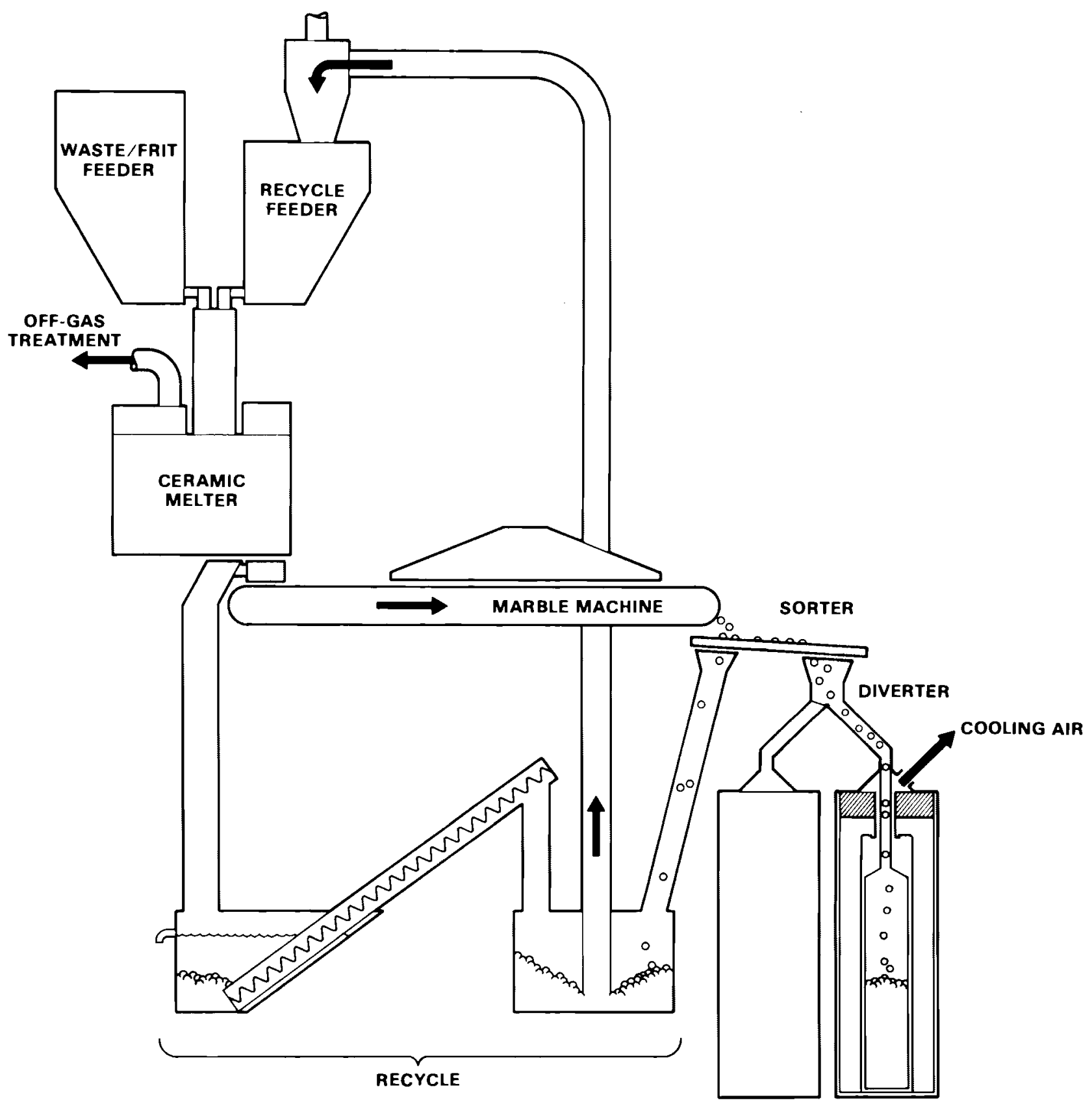

FIGURE 10. Glass Marble Production Schematic 
marbles is enhanced by blowing hot air through the marble mass.) When the mass of marbles reached the desired temperature range, lead shot was added to the canister. The test is summarized as Heat Number 17 in Table 1.

The product of this demonstration was a 40-cm (16-in.)-dia by $213-\mathrm{cm}$ (7-ft)-long stainless steel canister containing $\sim 310 \mathrm{~kg}$ of glass marbles encapsulated in $21429 \mathrm{~kg}$ of lead. Figure 11 is a photograph of the filled canister. The waste-glass marbles, $\sim 12 \mathrm{~mm}$ in dia, were made from simulated Savannah River TDS calcine and 211 frit in the composition noted in the Appendix. Number 4 lead shot $(3.3 \mathrm{~mm}$ dia) of the composition noted in the Appendix was used.

This full-scale canister of lead-encapsulated marbles was produced in an existing ICM furnace (Figure 12) that contains six separate heating zones. The test assembly was instrumented as shown in Figure 13. The temperature of the test assembly was raised by powering all of the heating zones in the ICM and by heating air that flowed into the assembly up to $450^{\circ} \mathrm{C}$. The temperature in the marbles was brought up to $450^{\circ} \mathrm{C}$ in $\sim 7 \mathrm{~h}$ and held overnight.

A vacuum of $22.5 \mathrm{~cm} \mathrm{H}_{2} \mathrm{O}$ was established in the test assembly and lead shot was gravity-fed through an airlock in 57-kilogram batches. As the lead falls in the annulus between the inner container and the canister, it melts. As Figure 14 shows, a total of $1383 \mathrm{~kg}(3050 \mathrm{lb})$ of lead shot was added in $2 \mathrm{~h}$ and $50 \mathrm{~min}$ for an overa 11 rate of $488 \mathrm{~kg} / \mathrm{h}$. No 1ong-term temperature changes were noted, except that the thermocouple located just above the inner container never registered above $300^{\circ} \mathrm{C}$ while the shot was being added.

Next, the power was turned off in the two lowest heating zones, and forced-air cooling was introduced in the lowest zone. Target temperatures for each of the six zones were monitored, and zone heating and cooling were controlled for a $9-h$ period. This permitted molten lead to fill voids that are created when the lead densifies as it passes from liquid to solid state. During this cooldown step, an additional $46 \mathrm{~kg}$ of lead shot were added to maintain the desired level of lead in the canister. 


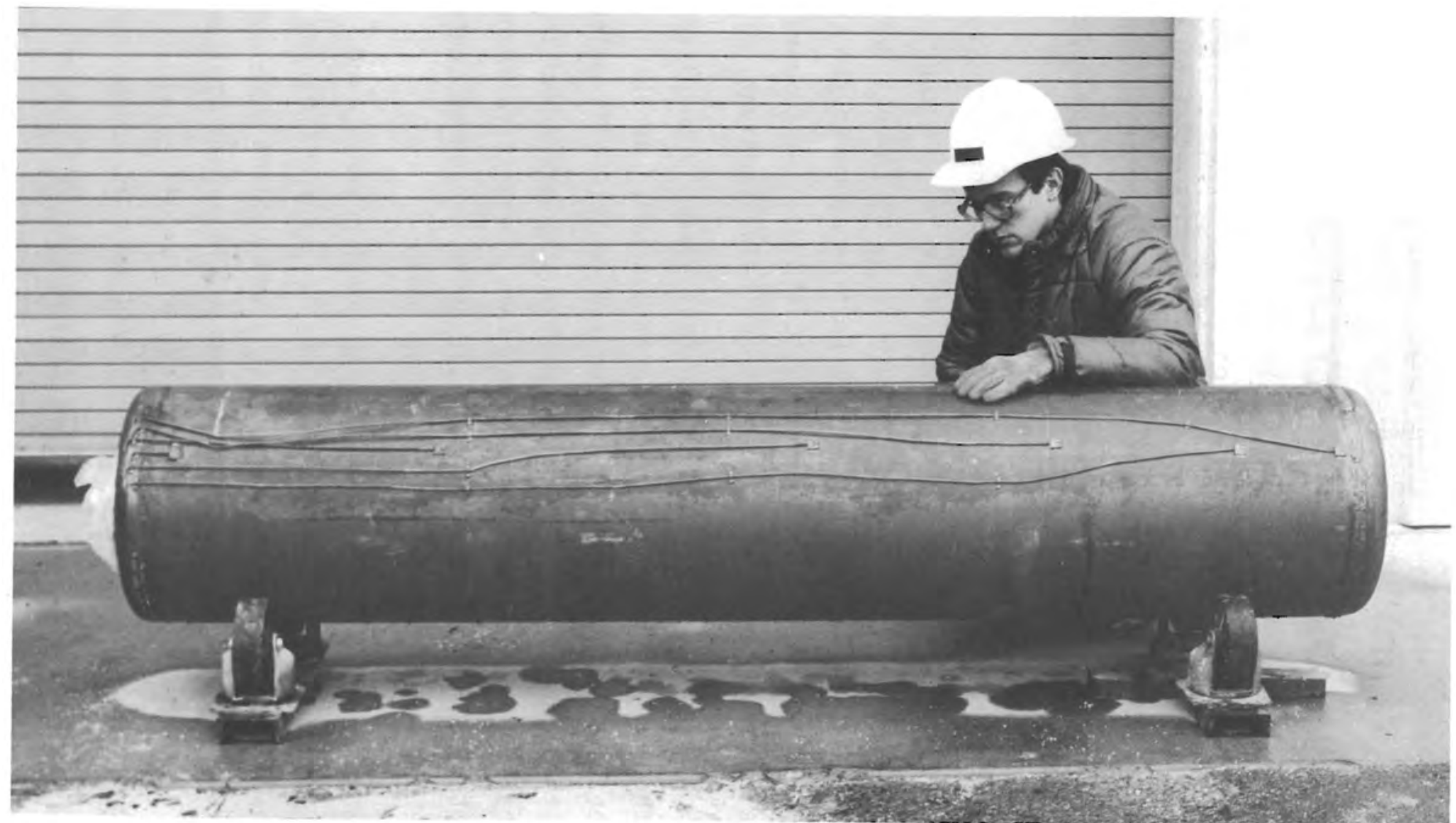

FIGURE 11. Full-Scale In-Can Encapsulation of Marbles in Lead 


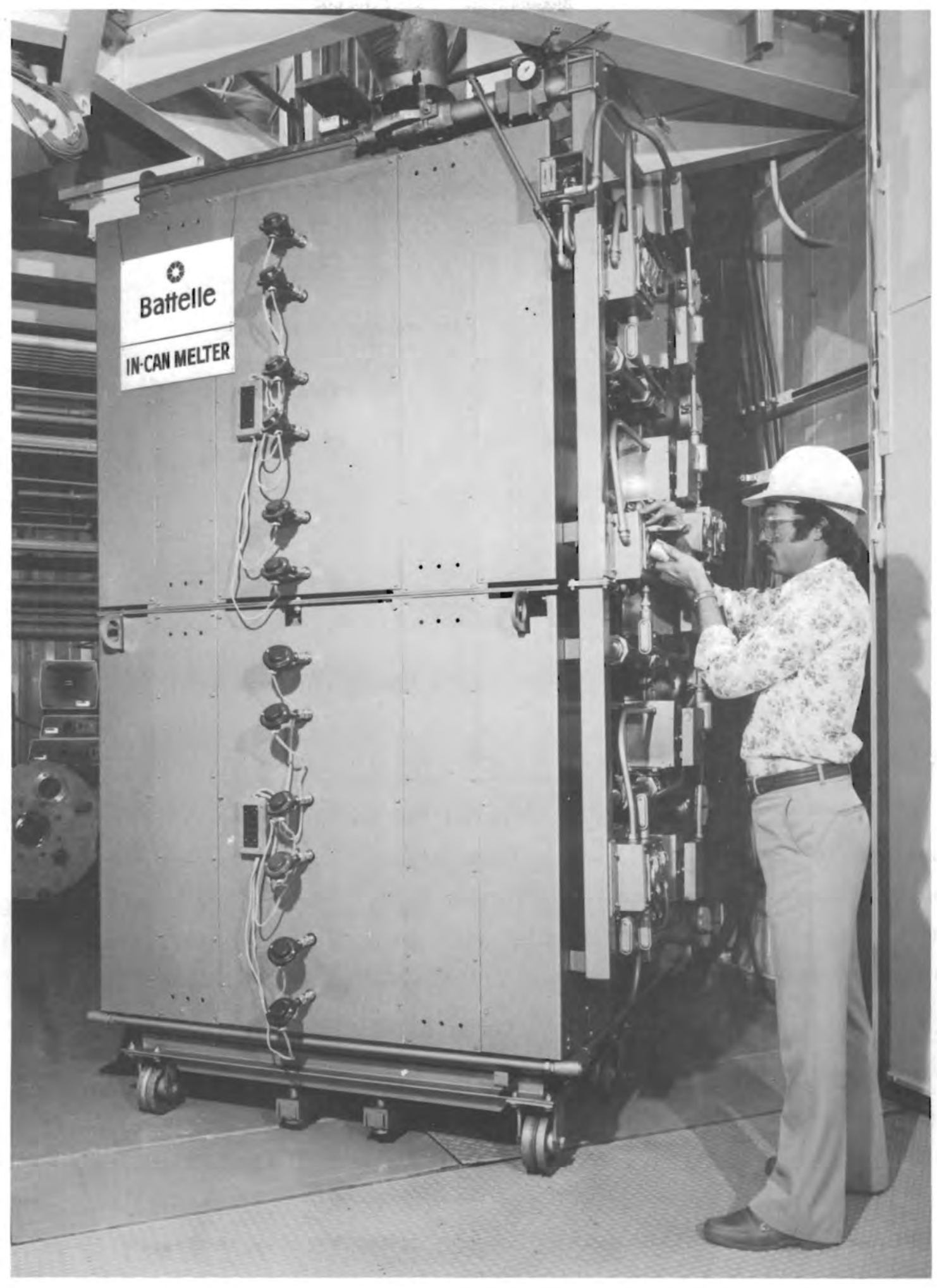

FIGURE 12. Full-Scale In-Can Melter 


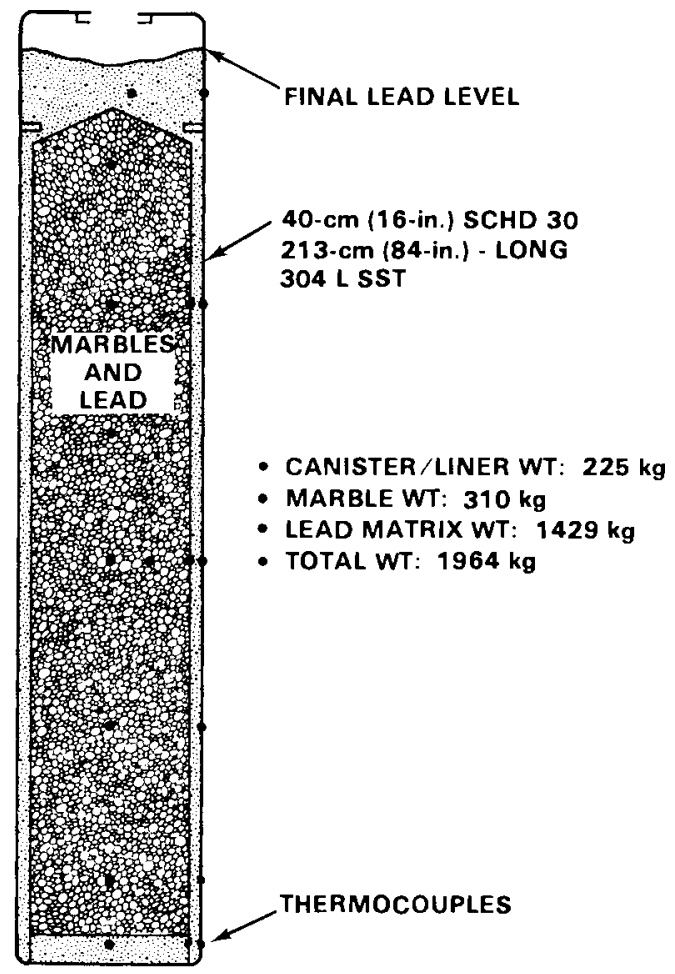

FIGURE 13. Fu11-Scale Marble-In-Lead Canister

\section{ALUMINUM-12 WT\% SILICON ALLOY--CERAMIC PELLETS AND GLASS MARBLES}

This series of tests demonstrated the encapsulation of simulated waste pellets in an aluminum-12 wt\% silicon alloy. Both laboratory-scale and engineering-scale tests were performed using gravity- and vacuum-casting of molten metal. Also, glass marbles were encapsulated in the aluminum alloy on a laboratory-scale.

\section{Laboratory-Scale Aluminum Alloy--Ceramic Pellets and Glass Marbles}

In the laboratory-scale tests, capsules $10 \mathrm{~cm}$ (4 in.) in dia by $15 \mathrm{~cm}$ (6 in.) long containing ceramic pellets and glass marbles were infiltrated with metal matrix by immersion in a furnace. A summary of the capsule tests is shown as Heat Number 8 in Table 1 . The method used to fill these capsules with A1-12 wt\% Si matrix metal is shown schematically in Figure 15 and is described below. 


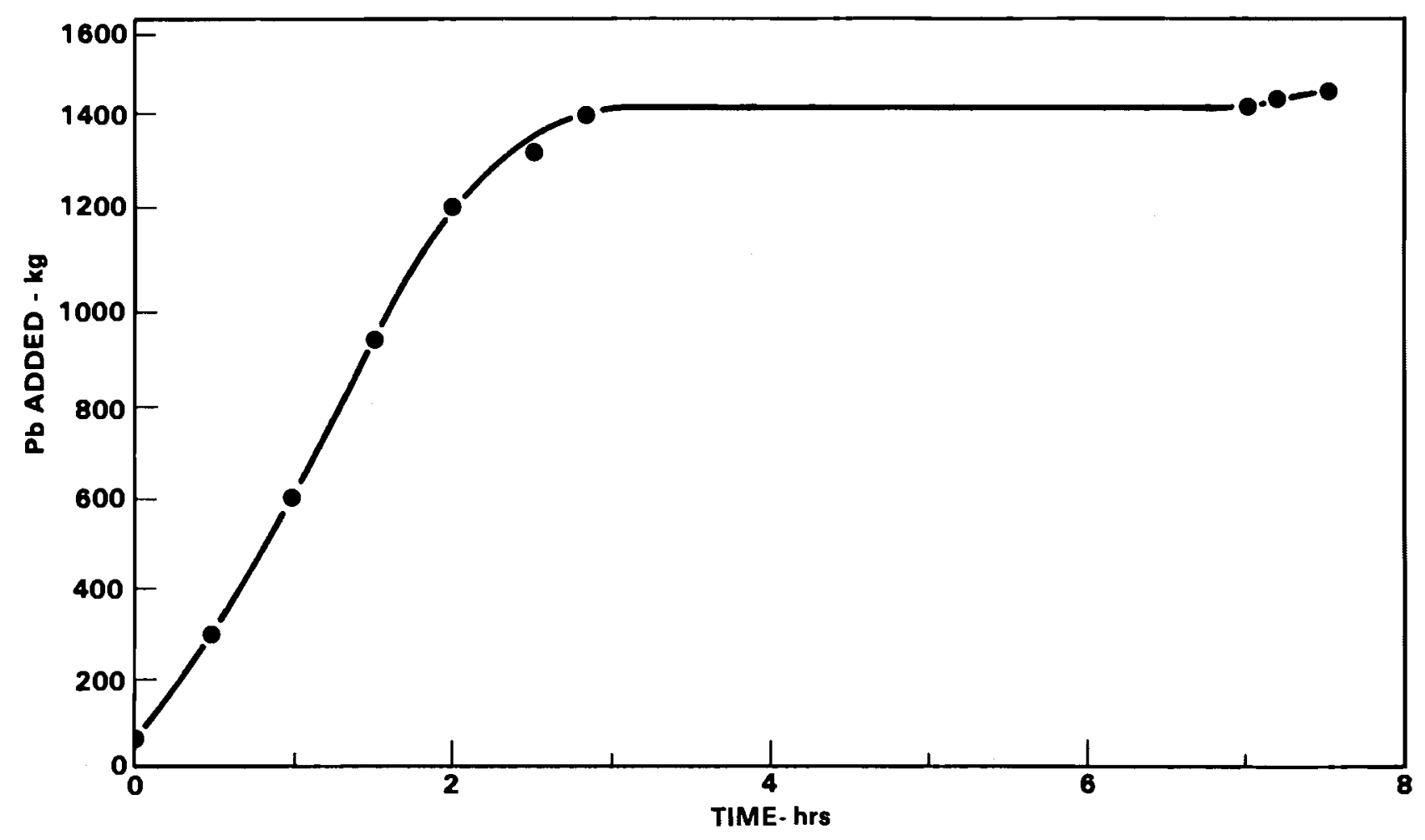

FIGURE 14. Full-Scale Lead-Filling Rate

\section{Capsule-Filling Procedure}

1. Preheat Capsule: $700^{\circ} \mathrm{C}$ for ceramic pellets $400^{\circ} \mathrm{C}$ for waste-glass marbles

2. Add Al-12 wt\% Si alloy fusion plug(a)

3. Evacuate capsule ${ }^{(a)}$

4. Crimp vacuum line partially closed $(a)$

5. Immerse capsule in $\mathrm{A} 1-12 \mathrm{wt} \%$ Si $700^{\circ} \mathrm{C}$ matrix metal

6. Remove and water-quench bottom surface.

(a) For vacuum-filling only

The first two capsule experiments showed that:

- ceramic pellets 2 to $4 \mathrm{~mm}$ in dia can be successfully vacuum-infiltrated with A1-12 wt\% Si matrix alloy (see Figure 16). 
๙

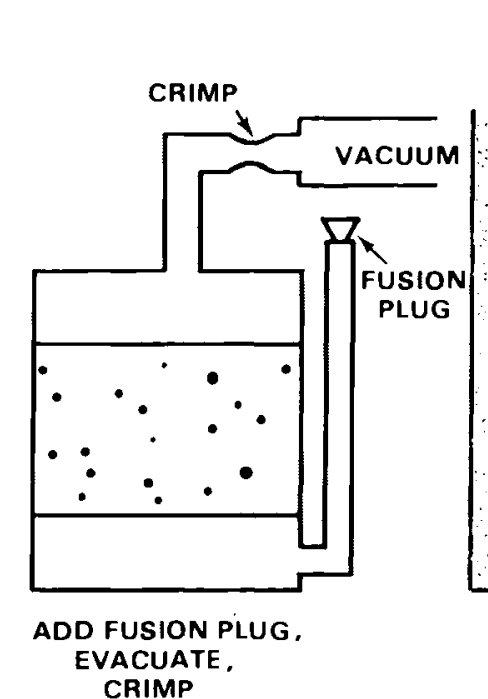

3

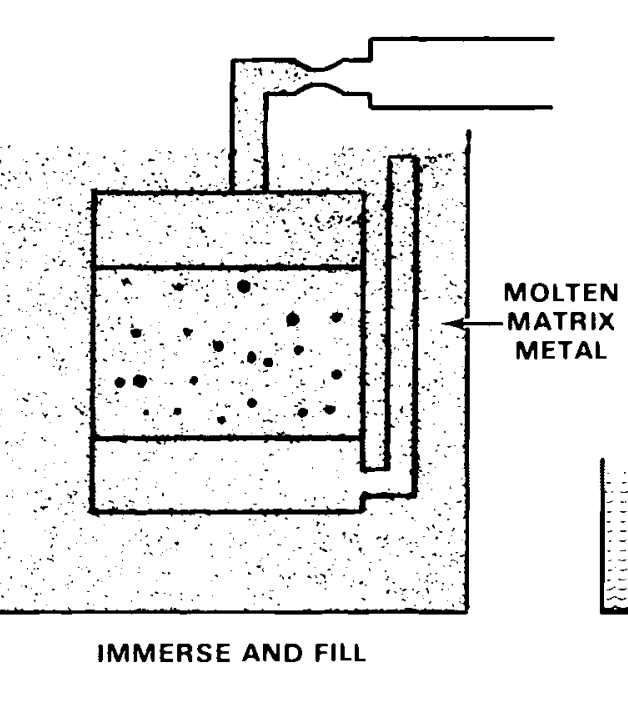

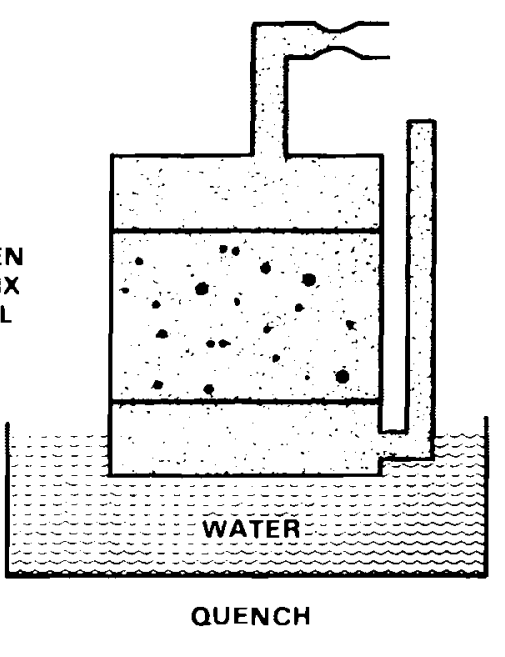

FIGURE 15. Schematic of Capsule-Filling Technique 


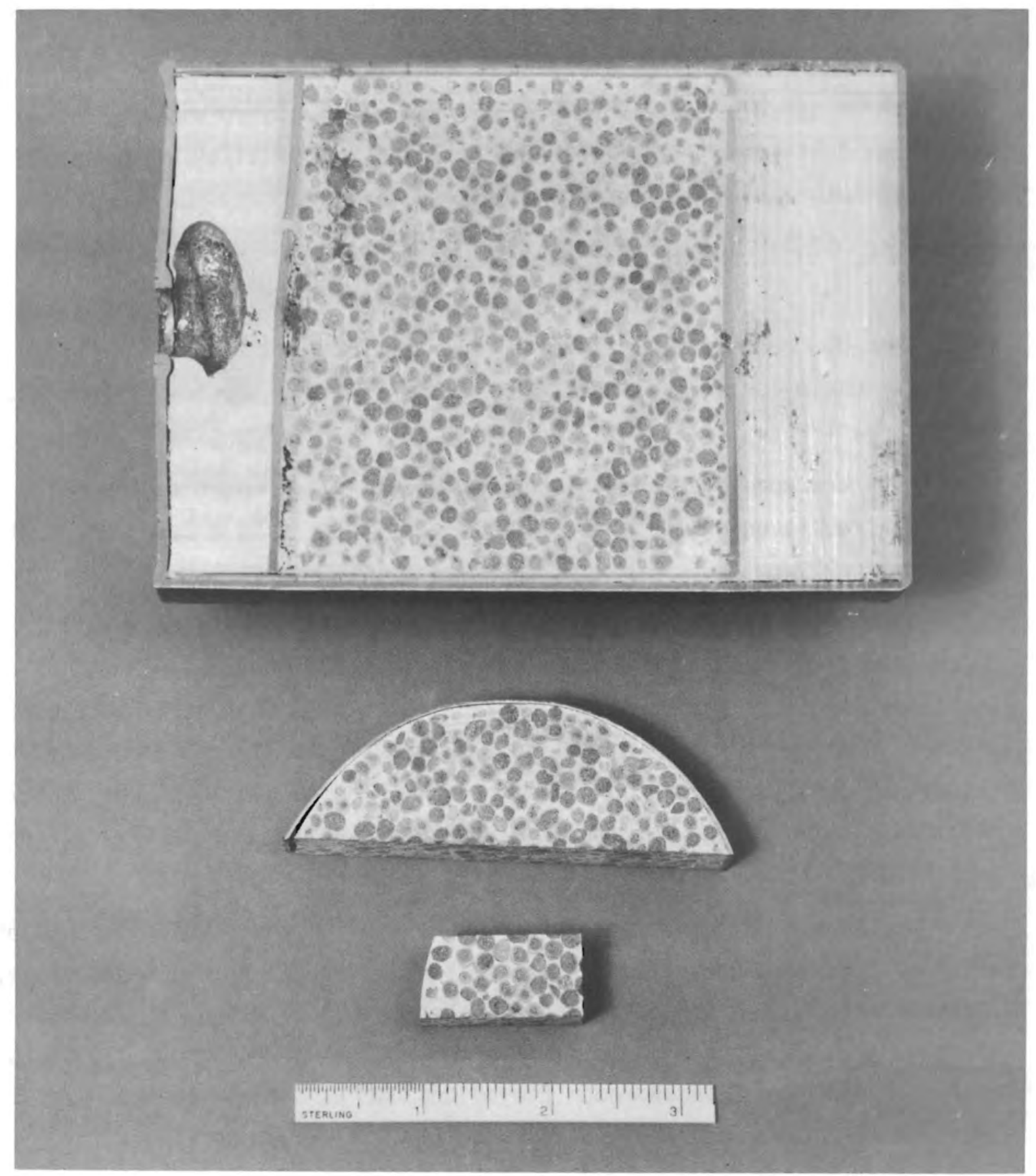

Waste Form: Ceramic Pellets 2 to $4 \mathrm{~mm}$ in Diameter Matrix: Aluminum 12 wt\% Silicon Alloy Heat Number: 8

FIGURE 16. Vacuum-Immersion Infiltrated Capsule--Pellets 
- ceramic pellets 4 to $5 \mathrm{~mm}$ in dia could not be gravity-infiltrated with Al-12 wt\% Si matrix alloy.

A third capsule containing 5- to 10-mm-dia simulated waste-glass marbles was successfully vacuum-infiltrated with Al-12 wt\% Si alloy at a capsule preheat temperature of $400^{\circ} \mathrm{C}$ (Figure 17 ).

Engineering-Scale Aluminum Alloy--Ceramic Pellets

Because of the successful vacuum-infiltration results obtained with the 2- to 4-mm-dia ceramic pellets, development efforts were directed toward vacuum infiltration in larger canisters $-20 \mathrm{~cm}$ ( $8 \mathrm{in.}$ ) dia. The test approach and the equipment were the same as those used for lead alloy-glass marbles.

Test runs conducted on canister heatup times indicated that 9 to $11 \mathrm{~h}$ were required to bring the mass of ceramic pellets up to a temperature of $700^{\circ} \mathrm{C}$.

Heat Number 9 (see Table 1) was the first attempt to vacuum-infiltrate a 20-cm (8-in.)-dia canister containing ceramic pellets with Al-12 wt\% Si alloy. The loaded canister was preheated to $700^{\circ} \mathrm{C}$. The vacuum funnel had a 6061 aluminum fusion disk and a 9.5-mm (0.375-in.)-dia nozzle. The unheated funnel was attached to the preheated canister just prior to pouring. When the $700^{\circ} \mathrm{C}$ metal matrix was poured, it froze in the funnel and, consequently, did not penetrate the fusion disk.

Heat Number 10 was an attempt to eliminate the fusion disk because of the extremely rapid pumpdown time $(<5 s)$ of the canister. For this procedure, the canister with funnel attached was preheated to $700^{\circ} \mathrm{C}$. Then, the canister vacuum system was opened immediately after attaching the vacuum line, and the metal was poured. This approach failed because as soon as the metal reached the canister it was carried upwards and into the vacuum port.

Because of the limited supply of ceramic pellets and the need for additional testing, a small 15-cm (6-in.)-dia by 38-cm (15-in.)-deep test canister was fabricated. A 3-mm (0.125-in.)-thick Al-12 wt\% Si fusion disk with a melting point of $577^{\circ} \mathrm{C}$ was used with an $11-\mathrm{mm}(0.438-i n)-.d i a$ nozzle. The canister-vacuum funnel assembly was preheated to $500^{\circ} \mathrm{C}$ before pouring. Heat 


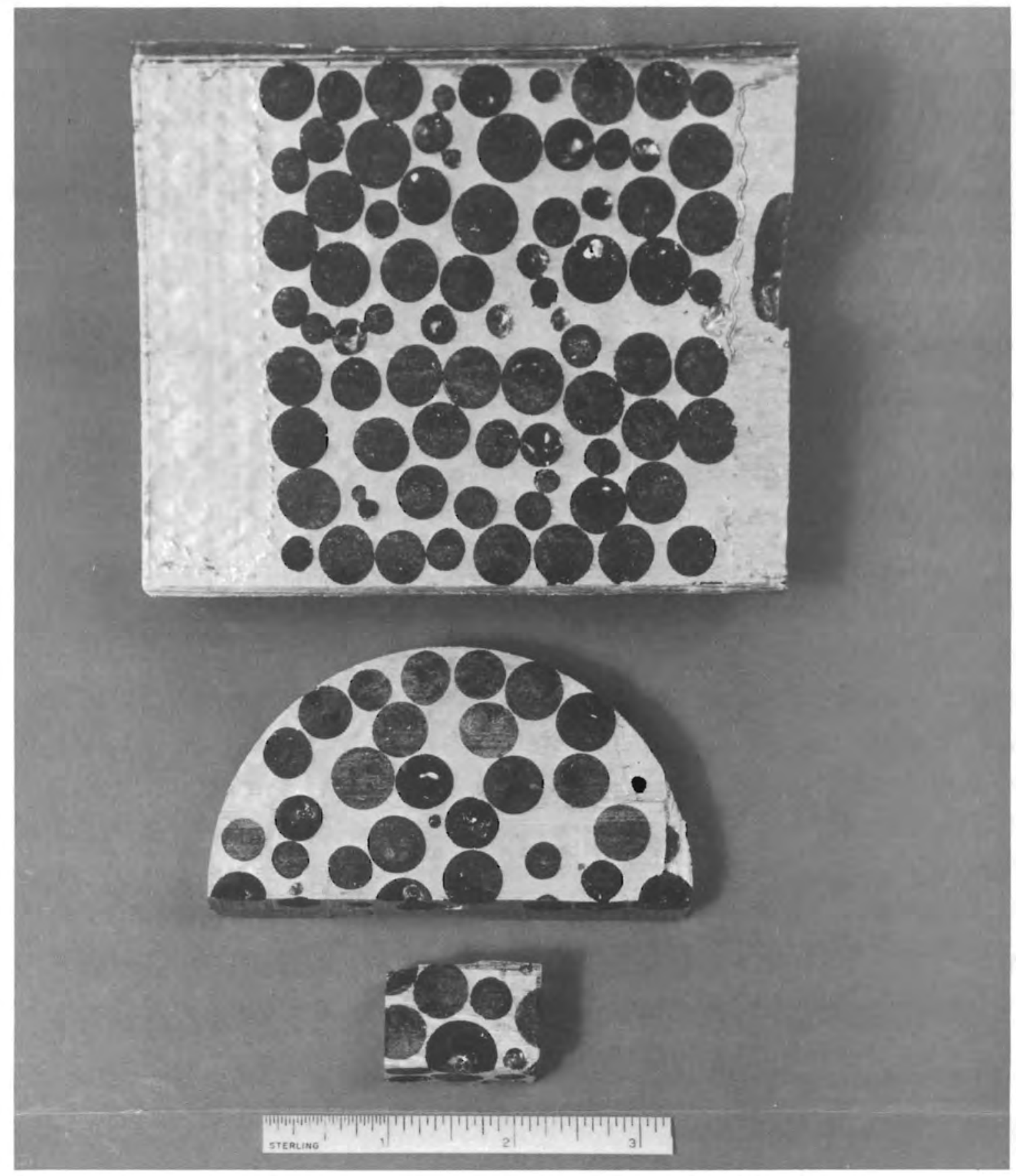

Waste Form: Glass Marbles 5 to $10 \mathrm{~mm}$ in Diameter Matrix: Aluminum 12 wt\% Silicon Alloy

Heat Number: 8

FIGURE 17. Vacuum-Immersion Infiltrated Capsule--Marbles 
Number 12 was a test of this pouring configuration and preheat temperatures. The $700^{\circ} \mathrm{C}$ matrix metal poured through the Al-12 wt\% Si fusion disk without any problems. However, the nozzle was apparently too large since the sound of periodic vacuum breaks were evident during the pour.

Heat Number 13 was similar to Heat Number 12. A 13.4-cm (5.3-in.)-dia by 13.4-cm (5.3-in.)-long inner container loaded with 2- to 5-mm-dia ceramic pellets was inserted in a $15-\mathrm{cm}$ (6-in.)-dia test canister. The nozzle diameter was reduced to $9.5 \mathrm{~mm}(0.375 \mathrm{in.})$. The loaded canister was preheated at $500^{\circ} \mathrm{C}$ overnight and the vacuum-funnel assembly preheated at $500^{\circ} \mathrm{C}$ just before pouring. The matrix metal was poured at $730^{\circ} \mathrm{C}$. There were some vacuum breaks during the pour, which indicated that the nozzle diameter was still too large. However, excellent results were achieved with full encapsulation of the waste particles, as shown in Figure 18.

Ceramic pellets 4 to $9 \mathrm{~mm}$ in dia were used for Heat Number 14 . A $20-\mathrm{cm}$ (8-in.)-dia canister was loaded with $34 \mathrm{~kg}$ of pellets. Forty-five kilograms of Al-12 wt\% Si alloy at $730^{\circ} \mathrm{C}$ were vacuum-poured into the canister in $37 \mathrm{~s}$. A nozzle with a diameter of $8.7 \mathrm{~mm}(0.344 \mathrm{in.})$ (Figure 6B) was used, and no vacuum breaks were detected during the pour. Excellent results were achieved with full metal-matrix penetration of the pellet stack, as shown in Figure 19. The casting procedure used for lead alloy-glass marbles (see page 12) was used for vacuum-infiltrating these ceramic pellets during Heat Numbers 9 through 14. However, an additional step, $4 a$, was included in the procedures as listed:

4a. Two to four hours prior to pouring, remove canister from preheat furnace and attach funnel assembly with fusion disk in place. Return assembly to preheat furnace. (a)

(a) It is not known at this time what the effect of the prolonged (9 to $11 \mathrm{~h}$ ) preheat time required to bring the ceramic pellets up to temperature will have on the integrity of the 3-mm (0.125-in.)-thick A1-12 wt\% Si fusion disk. Therefore, preheat time for the funnel assembly is kept to a minimum. 


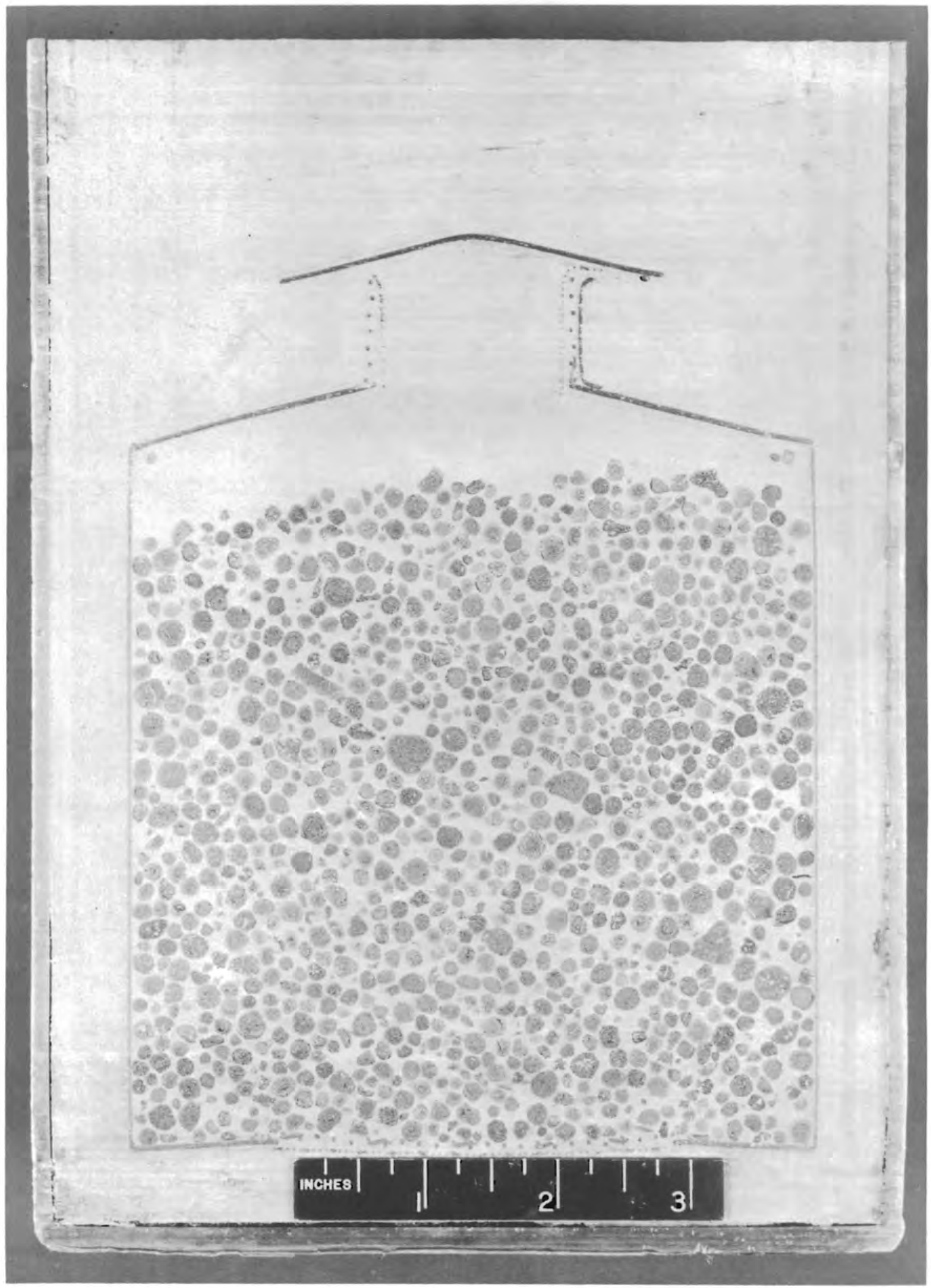

FIGURE 18. Vacuum Infiltration of Al-12 Wt\% Si Ceramic Pellets 


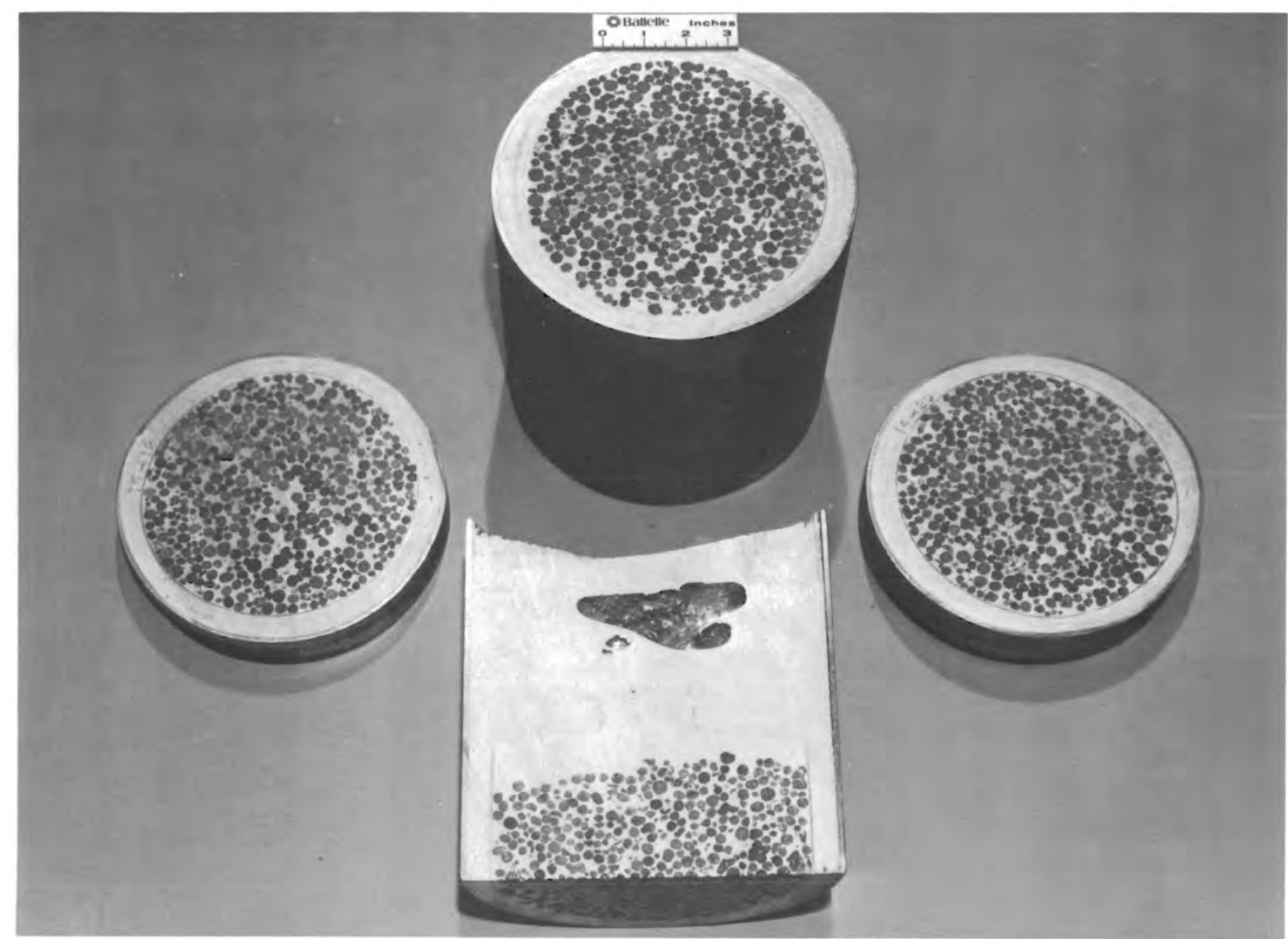

Waste Form: $34 \mathrm{~kg}$ Ceramic Pellets 4 to $9 \mathrm{mim}$ in Diameter Matrix: $45 \mathrm{~kg}$ Aluminum 12 wt\% Silicon Alloy Heat Number: 14

FIGURE 19. Vacuum-Cast Aluminum-Silicon Alloy Matrix--Pellets 
PRODUCT EVALUATION

Several cross sections, both vertical and horizontal, were cut in the various test containers and canisters so that the results of the various casting procedures could be evaluated. Typical sections are shown in Figures 7 , $9,16,17,18$ and 19 .

The alloys used in this investigation have excellent casting characteristics. As shown in the Appendix, commercial casting grades were used. The cast matrix-metal quality showed no evidence of gross impurities or porosity.

Figures 7 and 20 show sections of the engineering-scale vacuum casting performed on simulated waste-glass marbles with lead-tin alloy (Heat Number 6). Figure 21 indicates the configuration of the marbles in gravity-cast lead-tin alloy (Heat Number 7). Figures 9 and 22 show some of the sections and micrographs made after the enginering-scale tests were performed with waste-glass marbles in lead shot (Heat Numbers 15 and 16). These figures show that the lead encapsulated the marbles very well. No voids or inclusions are in the lead, and only occasional small gaps are evident at some of the marble contact points.

Figures 19 and 23 depict the configuration of ceramic pellets vacuum cast in an Al-Si alloy (Heat Number 14). These photographs show that the simulated waste pellets are entirely encapsulated by the Al-Si matrix and that there are no detrimental voids or inclusions in the metal matrix. Figures 20A, 21A, 22A and $23 \mathrm{~A}$ are photographs of the contact surface between the waste-matrix mixture and the inner container wall. The diameters of the exposed waste particles are an indication of the degree of infiltration. Figures 20 and 23 are of vacuum-cast, metal matrix, whereas Figures 21 and 22 are of gravity-cast metal matrix. Bonding of the matrix metals or the waste forms to the container did not occur. All container components were fabricated from 304L stainless steel. Figure 24 is a section of Figure 17 showing the infiltration by the capsuleimmersion technique of waste-glass marbles with 12 wt\% Si alloy. By limiting the preheat temperature of the glass marbles to $400^{\circ} \mathrm{C}$ and instantaneously 


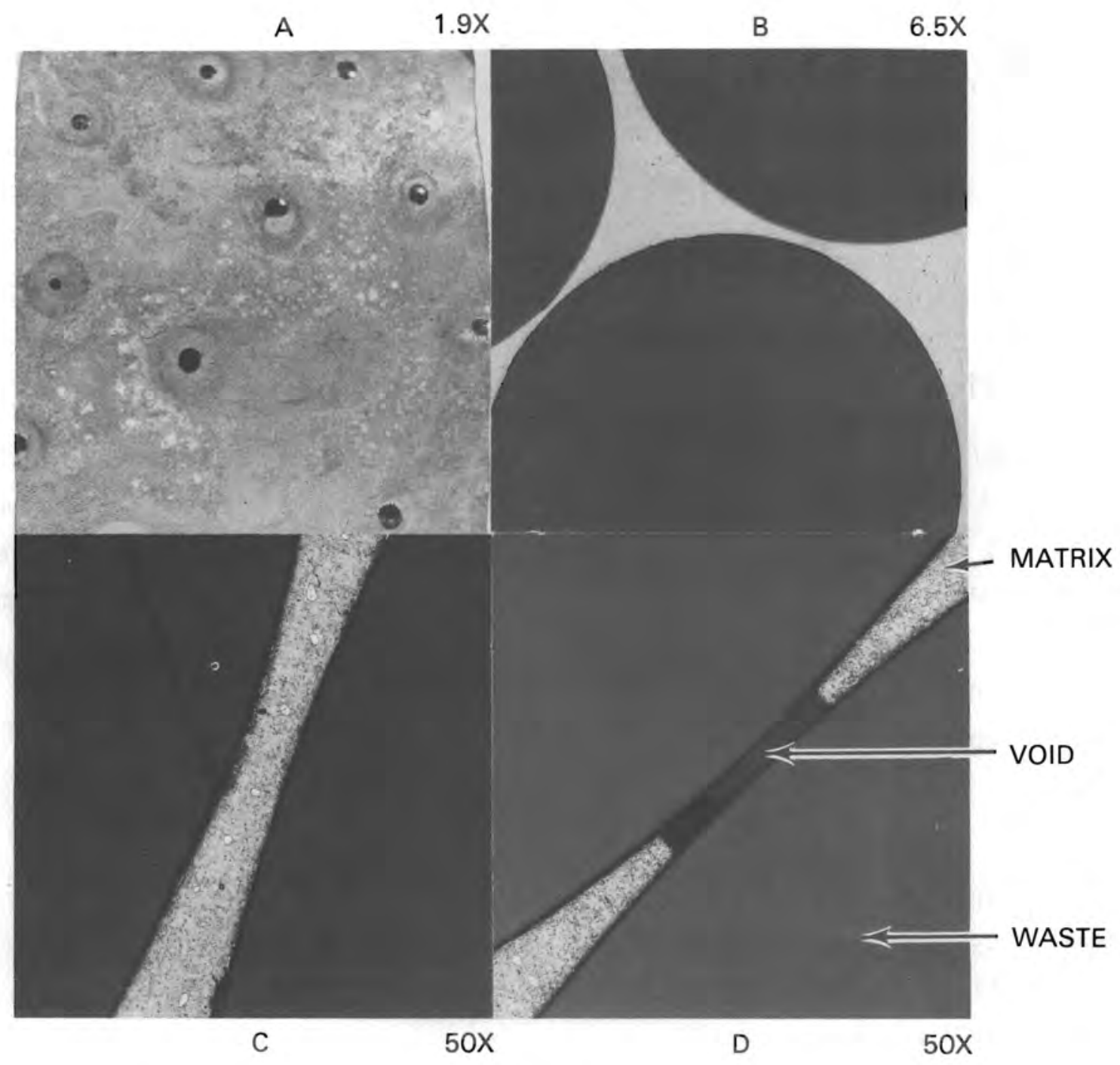

WASTE FORM: SIMULATED WASTE-GLASS MARBLES

MATRIX: LEAD-10 WT\% TIN ALLOY

HEAT NUMBER: 6

\section{FIGURE 20. Vacuum-Cast Lead-Tin Matrix}

infiltrating the marble stack with $700^{\circ} \mathrm{C}$ matrix metal, the distortion of the low softening point ( $\sim 500$ to $550^{\circ} \mathrm{C}$ ) of the glass marbles is minimized. Occasional welding of the glass marbles to each other at their contact points is noted in Figure 17. 


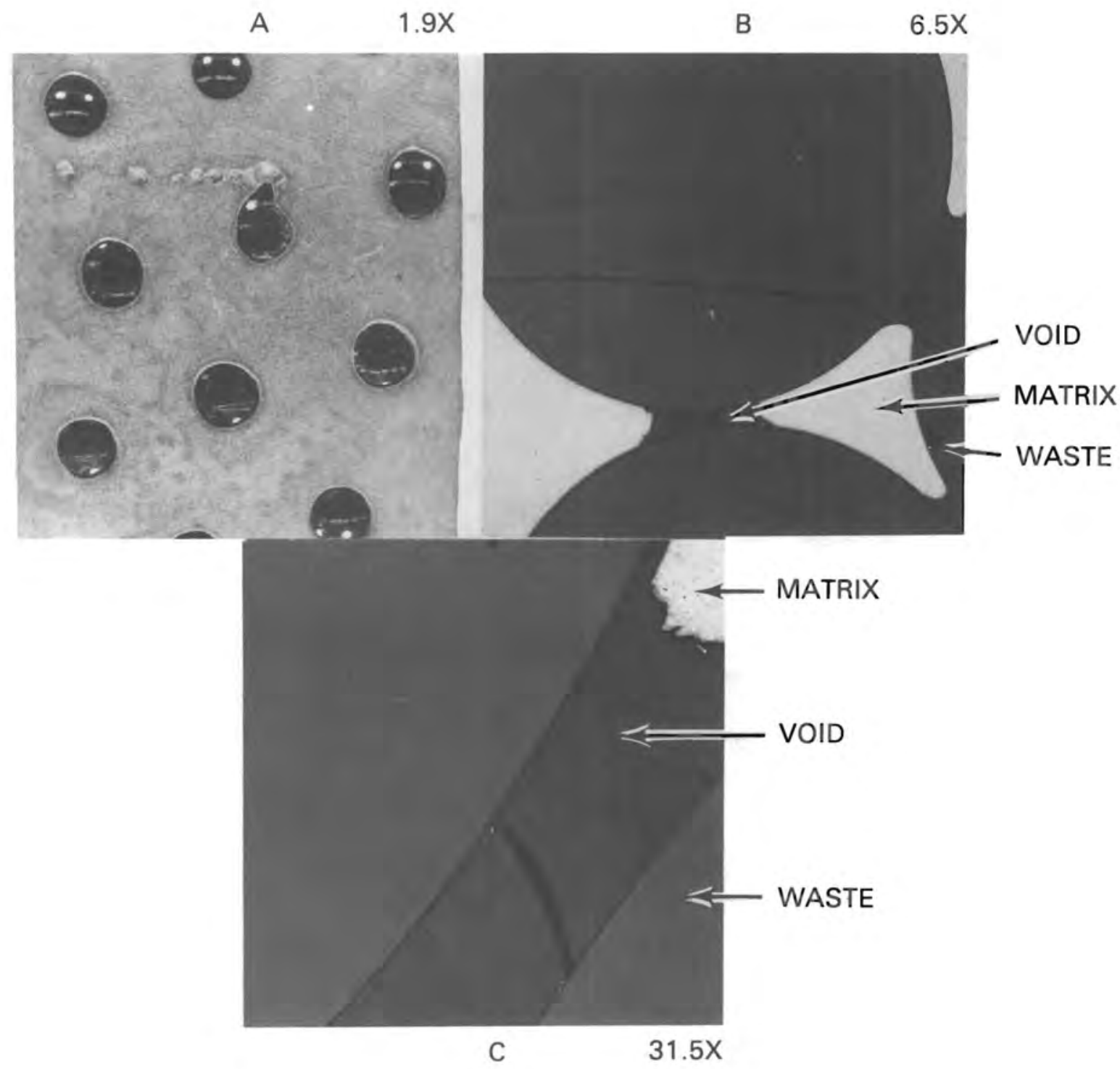

WASTE FORM: SIMULATED WASTE-GLASS MARBLES MATRIX: LEAD-10 WT\% TIN ALLOY

HEAT NUMBER: 7

FIGURE 21. Gravity-Cast Lead-Tin Matrix

When Figures 20 through 23 are compared, it appears that vacuum-casting A1-12 wt\% Si alloy with ceramic pellets offers the greatest degree of infiltration or encapsulation, although this has not been quantitatively determined. 


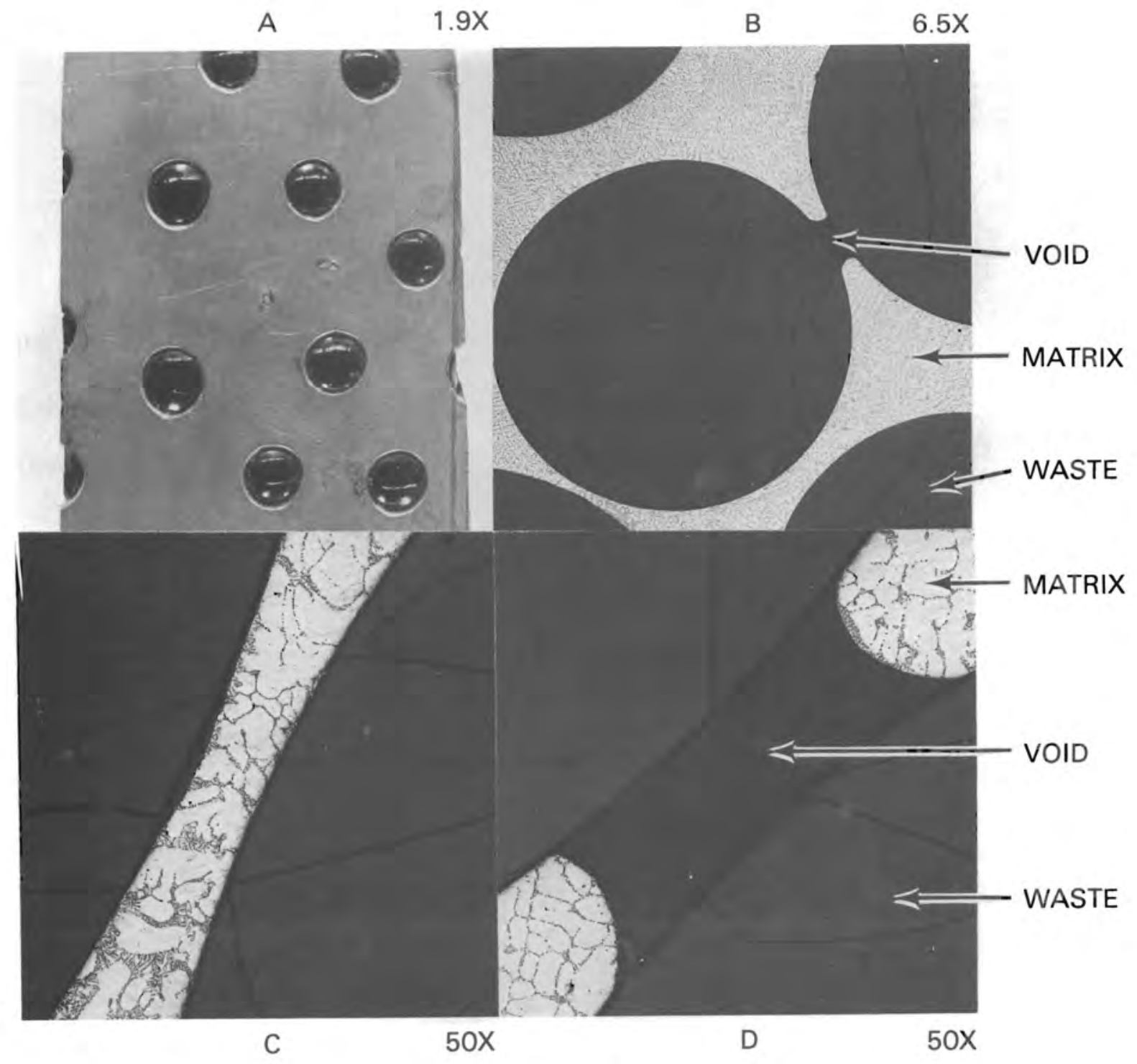

WASTE FORM: BOROSILICATE GLASS MARBLES

MATRIX: LEAD-3 WT\% ANTIMONY ALLOY

HEAT NUMBER: 16

FIGURE 22. Gravity-Cast Lead-Shot Feed

Figures 21 and 22 indicate that the $\mathrm{Pb}-3$ wt\% Sb alloy and the Pb-10 wt\% Sn alloy have about the same degree of infiltration when each are cast by the gravity technique. 


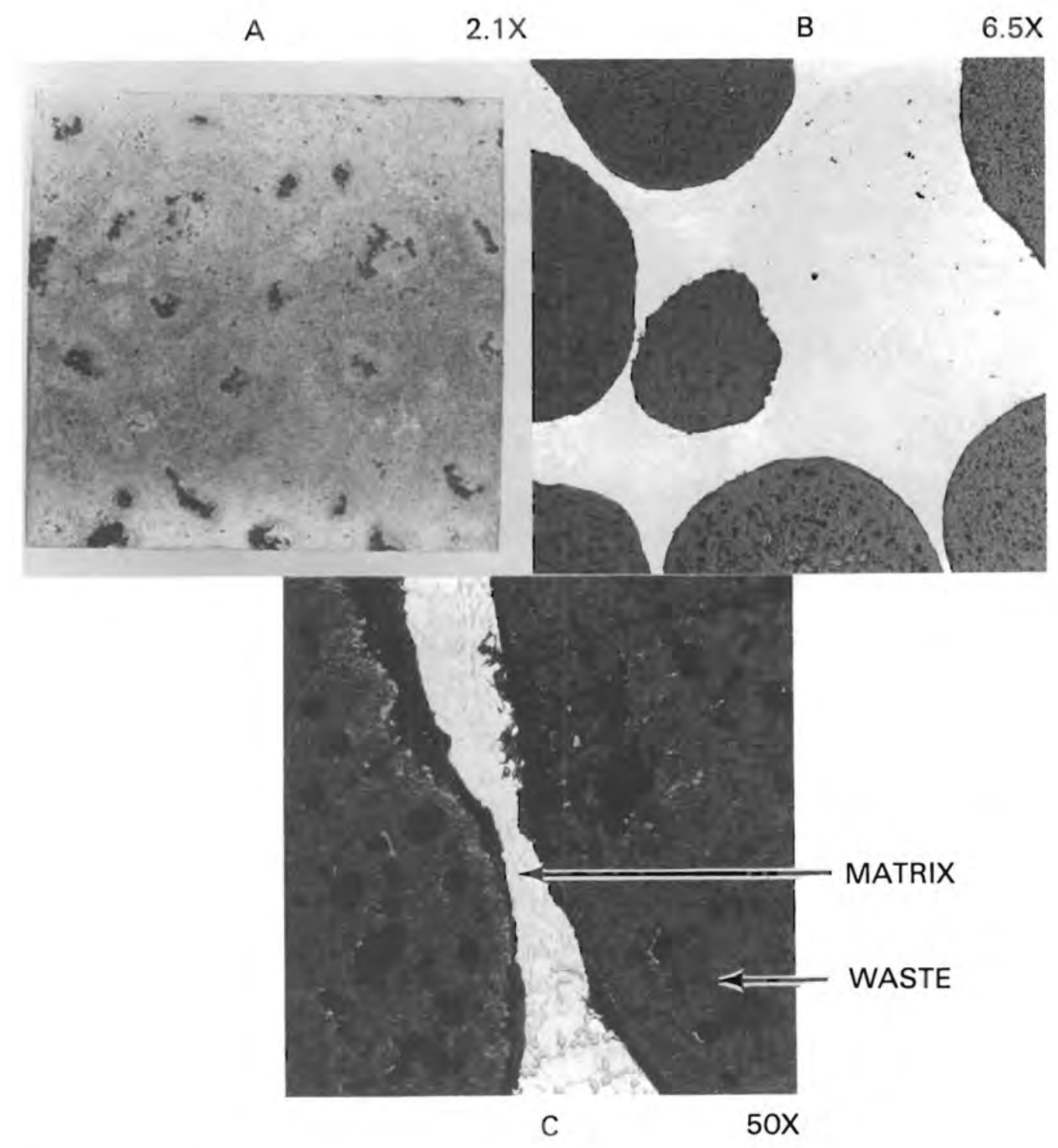

WASTE FORM: CERAMIC PELLETS

MATRIX: ALUMINUM 12 WT\% SILICON ALLOY

HEAT NUMBER: 14

FIGURE 23. Vacuum-Cast Aluminum-Silicon Matrix

It is planned to perform an impact test on the full-scale canister (40 cm dia $\times 213 \mathrm{~cm}$ long) (Figure 11) and to evaluate it and its contents. After completion of the impact test, cross-sectional cuts will be made in this 


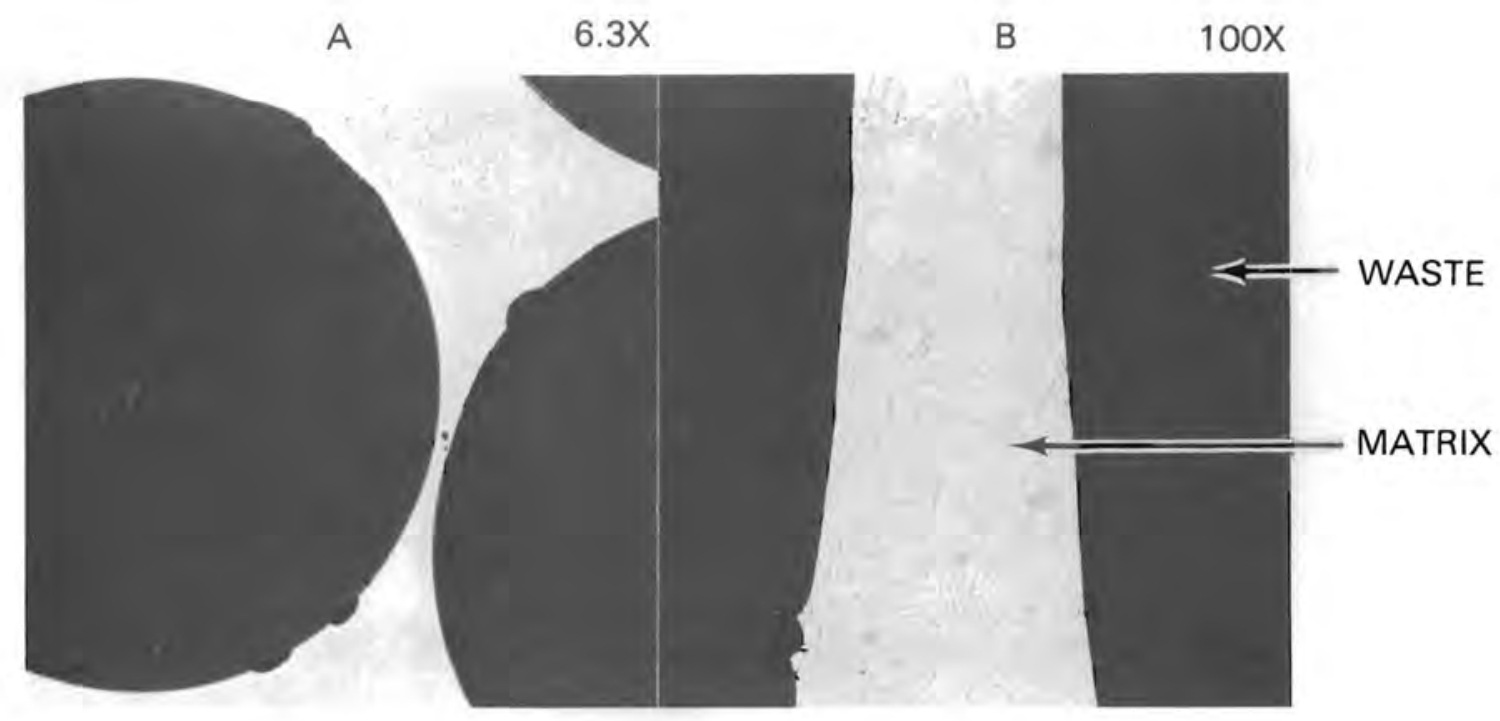

WASTE FORM: SIMULATED WASTE-GLASS MARBLES MATRIX: ALUMINUM 12 WT\% SILICON ALLOY HEAT NUMBER: 8

\section{FIGURE 24. Vacuum-Immersion Infiltrated Capsule--Marbles}

canister to allow evaluation of the metal-matrix infiltration of the marble stack. Also, it is planned to remove small sections of the test product for detailed examination and evaluation of the metal matrix and waste forms, and of their integrity and leach resistance. 


\section{DISCUSSION}

The vacuum-casting method forces the matrix metal deeper into the interstices of the waste-particle stack than does gravity casting. This increases the contact area of the waste particles in relation to the matrix metal, which probably results in a higher heat-carrying capacity of the infiltrated waste form and which may increase its leach resistance. The integrity of the matrixmetal annulus surrounding the inner can of encapsulated waste remains the same with either vacuum or gravity casting.

Borosilicate glass marbles with a softening point of $\sim 500$ to $550^{\circ} \mathrm{C}$ can be successfully infiltrated with the $\mathrm{Al}-12$ wt\% Si alloy at $700^{\circ} \mathrm{C}$ by vacuumimmersion techniques, if the marble preheat temperature is limited to $400^{\circ} \mathrm{C}$. However, during the tests reported here, an occasional marble-to-marble weld was noted. If large-scale work is anticipated using these materials, tests should be performed to determine the optimum preheat time, temperature and loading geometry to eliminate or minimize marble agglomeration during preheat.

The vacuum casting of the Al-12 wt\% Si alloy was successful with the 2- to 5-mm (Heat Number 13) and 4- to 9-mm (Heat Number 14)-dia ceramic pellets. Capsule-immersion techniques were successful with 2- to 4-mm-dia ceramic pellets using vacuum but failed with 4- to 5-mm-dia pellets using gravity (Heat Number 8). Therefore, the lower ceramic particle-size limit for successful vacuum infiltration is $<2$ to $4 \mathrm{~mm}$ dia; for gravity casting, this limit is between 4 and $10 \mathrm{~mm}$ dia. While there are indications that the vacuum-cast Al-12 wt\% Si alloy may have the greatest infiltration characteristics, its selection and use as a matrix material will depend on its ability to contain the radionuclides.

Gravity casting is the simplest process to perform remotely. In either gravity casting or vacuum casting, the matrix metal could be melted outside the cell and brought into the cell in pouring ladles, or piped into the cell. The ICE version of gravity casting eliminates the need to bring molten metal into the remote cell. 
For vacuum pouring, this investigation used a fusion disk that was melted by the incoming molten metal. Alternative methods should also be considered. These could include a freeze plug that would be melted by an auxiliary heater, or a valve, either of which would be directly coupled to a bottom-pouring ladle.

The tests showed how much time is required to preheat, by conduction, the glass marbles or the ceramic pellets and their containers. In a process involving actual HLW, the preheating requirement would be reduced or even eliminated due to the decay heat of the waste forms.

The ICE tests indicated that the lead-fill rate was very conservative and that this could be increased with either 1 arge (8-mm) or small (2-mm)-dia lead shot. Although up to $2.5 \mathrm{~cm}$ of dross was on the top of the test canisters, this did not appear to affect the melting or flowing of the lead shot.

The laboratory- and engineering-scale demonstrations confirmed that a water quench on the bottom of the canister is an effective method to cool the mass and to control shrinkage voids. Preliminary results indicated that forced-air cooling was satisfactory on the full-scale tests. 


\section{REFERENCES}

Be11, D. C., H. S. Cole and E. G. Samse1. 1976. "Post-Calcination Treatment of Commercial Wastes." In Waste Management Development Technical Progress Report. ICP-1098, Allied Chemical Corp., Idaho Fal1s, Idaho.

Berreth, J. R., H. S. Cole, E. G. Samsel and L. C. Lewis. 1976. Development and Evaluation of Alternative Treatment Methods for Commercial and ICPP HighLevel Solidified Wastes. ICP-1089, AlTied Chemical Corp., Idaho Falls, Idaho.

Dierks, R. D. 1980. The Design and Performance of a 100-kg/h, Direct CalcineFed Electric-Melter System for Nuclear-Waste Vitrification. PNL-3387, Pac if ic Northwest Laboratory, Richland, Washington.

Jardine, L. J. and M. J. Steindler. 1978. A Review of Metal-Matrix Encapsulation of Solidified Radioactive High-Level Waste. ANL-78-19, Argonne National Laboratory, Argonne, Illinois.

Johnson, E. R., Associates, Inc. 1980. Preliminary Evaluation of Alternative Waste Form Solidification Processes Volume 11: Evaluations of the Processes. PNL-3477, JAI-160, Pacific Northwest Laboratory, Richland, Washington.

McCarthy, G. D. 1977. "High-Level Waste Ceramics Material Considerations, Process Simulation and Product Characteristics." Nuc. Tech. 32:92-105.

Platt, A. M. and J. A. Powe 11, comps. 1980. Nuclear Waste Management Quarter ly Progress Report Apri1 Through June 1980. PNL-3000-6, Pacific Northwest Laboratory, Richland, Washington.

Rhodes, D. W. 1969. Post-Calcination Treatment Possibilities for Calcine from Fluidized Bed Calcination. IN-1322, Idaho Nuclear Engineering Laboratory, Idaho Falls, Idaho.

Rusin, J. M. et al. 1978. Multibarrier Waste Forms, Part I: Development. PNL-2668-1, Pacific Northwest Laboratory, Richland, Washington.

Rusin, J. M. et al. 1979. Multibarrier Waste Forms, Part II: Characterization and Evaluation. PNL-2668-2, Pacific Northwest Laboratory, Richland, Washington.

Stone, J. A., S. T. Goforth, Jr. and P. K. Smith. 1979. Preliminary Evaluation of Alternative Forms for Immobilization of Savannah River Plant HighLeve 1 Waste. DP-1545, E. I. duPont de Nemours and Co. (Inc.), Savannah River Laboratory, Aiken, South Carolina.

Sump, K. R. 1976a (January). Quarterly Progress Report, Research and Development Activities, Waste Fixation Program. BNWL-1949 (Metal Matrix), Pacific Northwest Laboratory, Richland, Washington. 
Sump, K. R. 1976b (April). Quarterly Progress Report, Research and Development Activities, Waste Fixation Program. BNWL-1994 (Metal Matrix), Pacific Northwest Laboratory, Richland, Washington.

Sump, K. R. and S. Begej. 1976. Quarterly Progress Report, Research and Development Activities, Waste Fixation Program. BNWL-2070 (Metal Matrix), Pacific Northwest Laboratory, Richland, Washington.

Treat, R. L. et al. 1980. Preliminary Evaluation of Alternative Waste Form Solidification Processes Volume 1: Identification of the Processes. PNL3244, Pacific Northwest Laboratory, Richland, Washington.

VanGeel, J., H. Eschrich and E. Detilleus. 1975. "Conditioning of Solid High-Level Waste Products by Dispersion into Metal Matrices." Presented at Los Angeles AIChE Meeting, November 18, 1975, Eurochemic, Mol. Belgium. 
APPENDIX

CASTING MATERIALS AND COMPOSITION

OF SIMULATED WASTE FORMS 


\section{CASTING MATERIALS AND COMPOSITION \\ OF SIMULATED WASTE FORMS}

\section{TABLE A.1. Melt Stock}

\section{A. Lead}

- Pure lead pig.

- Pure lead pig corroding grade in compliance with ASTM B 29-55.

- 90 wt\% Pb-10 wt\% Sn solder alloy pig, Grade 10B in compliance with ASTM B32-76.

- Lead Shot Number 4: $3.3 \mathrm{~mm}$ (0.13 in.) dia chilled in accordance with American standards for chilled shot and containing these elements in wt\%:

$\begin{array}{cc}\text { Elements } & \text { Weight Percent } \\ \mathrm{Sb} & 2.05 \\ \mathrm{Sn} & 0.20 \\ \mathrm{As} & 0.11 \\ \mathrm{Cu} & 0.033 \\ \mathrm{Fe} & <0.001 \\ \mathrm{Ni} & <0.001 \\ \mathrm{Bi} & 0.013 \\ \mathrm{Ag} & 0.002 \\ \mathrm{Zn} & <0.001\end{array}$

B. Aluminum-12 Wt\% Silicon

- Aluminum-12 wt\% silicon: die-cast alloy pig, Grade A 413.2 in compliance with ANSI/ASTM B 179-78 and containing these elements in wt\%:

\begin{tabular}{cc} 
Elements & Weight Percent \\
\cline { 2 - 2 } $\mathrm{Cu}$ & 0.02 \\
$\mathrm{Fe}$ & 0.30 \\
$\mathrm{Mg}$ & 0.02 \\
$\mathrm{Mn}$ & 0.01 \\
$\mathrm{Si}$ & 12.0 \\
$\mathrm{Zn}$ & 0.03 \\
$\mathrm{Cr}$ & 0.02 \\
$\mathrm{Ni}$ & 0.01 \\
$\mathrm{Ti}$ & 0.01
\end{tabular}


TABLE A.2. Composition of Simulated Waste-Glass Marbles

\begin{tabular}{|c|c|c|}
\hline \multicolumn{2}{|c|}{ Composition } & \multirow{2}{*}{$\begin{array}{c}\text { Density as } \\
\text { Determined by } \\
\text { Water Immersion }\end{array}$} \\
\hline 0xide Form & $w t \%$ & \\
\hline $\mathrm{Al}_{2} \mathrm{O}_{3}$ & 7.52 & $2.82 \mathrm{~g} / \mathrm{c}^{3}$ \\
\hline $\mathrm{B}_{2} \mathrm{O}_{3}$ & 9.22 & \\
\hline $\mathrm{BaO}$ & 0.83 & \\
\hline $\mathrm{CaO}$ & 4.01 & \\
\hline $\mathrm{Ce}_{2} \mathrm{O}_{3}$ & 0.83 & \\
\hline $\mathrm{Dy}_{2} \mathrm{O}_{3}$ & 0.16 & \\
\hline $\mathrm{Fe}_{2} \mathrm{O}_{3}$ & 5.48 & \\
\hline $\mathrm{La}_{2} \mathrm{O}_{3}$ & 0.52 & \\
\hline $\mathrm{Li}_{2} \mathrm{O}$ & 5.76 & \\
\hline $\mathrm{MgO}$ & 0.66 & \\
\hline $\mathrm{MnO}_{2}$ & 1.85 & \\
\hline $\mathrm{MoO}_{3}$ & 1.19 & \\
\hline $\mathrm{Na}_{2} \mathrm{O}$ & 9.21 & \\
\hline $\mathrm{Nd}_{2} \mathrm{O}_{3}$ & 0.47 & \\
\hline $\mathrm{NiO}$ & 0.57 & \\
\hline $\mathrm{SiO}_{2}$ & 39.2 & \\
\hline Sro & 0.73 & \\
\hline $\mathrm{TiO}_{2}$ & 0.19 & \\
\hline $\mathrm{ZnO}$ & 7.08 & \\
\hline $\mathrm{Co}_{2} \mathrm{O}_{3}$ & 0.08 & \\
\hline $\mathrm{Cr}_{2} \mathrm{O}_{3}$ & 0.12 & \\
\hline CuO & 0.03 & \\
\hline $\mathrm{Gd}_{2} \mathrm{O}_{3}$ & 0.08 & \\
\hline
\end{tabular}


TABLE A.3. Simulated-Waste Ceramic Pellets

\begin{tabular}{|c|c|c|}
\hline \multicolumn{2}{|c|}{ Composition } & \multirow{2}{*}{$\begin{array}{l}\text { Density as Determined } \\
\text { by Water Immersion }\end{array}$} \\
\hline 0xide Form & $w t \%$ & \\
\hline $\mathrm{AgO}_{2}$ & 0.12 & $3.57 \mathrm{~g} / \mathrm{c}^{3}$ \\
\hline $\mathrm{BaO}$ & 2.14 & \\
\hline $\mathrm{Cd} 0$ & 0.14 & \\
\hline $\mathrm{Cr}_{2} \mathrm{O}_{3}$ & 0.47 & \\
\hline $\mathrm{K}_{2} \mathrm{O}$ & 1.56 & \\
\hline $\mathrm{Fe}_{2} \mathrm{O}_{3}$ & 4.72 & \\
\hline $\mathrm{MoO}_{3}$ & 8.71 & \\
\hline $\mathrm{Na}_{2} \mathrm{O}$ & 0.16 & \\
\hline $\mathrm{NiO}$ & 1.43 & \\
\hline $\mathrm{P}_{2} \mathrm{O}_{5}$ & 3.75 & \\
\hline Sro & 1.45 & \\
\hline $\mathrm{ZrO}_{2}$ & 6.75 & \\
\hline $\mathrm{COO}$ & 0.39 & \\
\hline $\mathrm{CeO}_{2}$ & 5.98 & \\
\hline $\mathrm{M}_{2} \mathrm{O}_{3}$ & $37.58^{(a)}$ & \\
\hline $\mathrm{Al}_{2} \mathrm{O}_{3}$ & $3.99(b)$ & \\
\hline $\mathrm{CaO}$ & $1.83^{(b)}$ & \\
\hline $\mathrm{SiO}_{2}$ & $15.52^{(b)}$ & \\
\hline $\mathrm{SrO}^{2}$ & $3.31^{(b)}$ & \\
\hline
\end{tabular}

(a) Other rare earths

(b) Supercalcine additives 


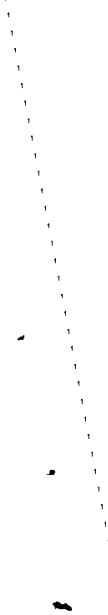

$-$ 
DISTRIBUTION

No. of

Copies

OFFSITE

A. A. Churm

DOE Chicago Patent Group

9800 South Cass Avenue

Argonne, IL 60439

R. Y. Lowrey

DOE Albuquerque Operations Office

P. 0. Box 5400

Albuquerque, NM 87185

A. L. Taboas

DOE Albuquerque Operations Office

P. 0. Box 5400

Albuquerque, NM 87185

S. A. Mann

DOE Chicago Operations and Region Office

Argonne, IL 60439

J. Neff

Department of Energy

Columbus Program Office

$505 \mathrm{King}$ Avenue

Columbus, $\mathrm{OH} 43201$

W. E. Mott

DOE Division of Environmental

Control Technology

Washington, DC 20545

J. P. Hamric

DOE Idaho Operations Office

550 2nd St.

Idaho Falls, ID 38401

J. W. Peel

DOE Idaho Operations Office

550 2nd St.

Idaho Falls, ID 38401
No. of

Copies

J. B. Whitsett

DOE Idaho Operations Office

550 2nd St.

Idaho Falls, ID 38401

C. R. Cooley

DOE Nuclear Waste Management Programs

NEW, B-107, HQ

Washington, DC 20545

G. H. Daly

DOE Nuclear Waste Management Programs

NEW, B-107, HQ

Washington, DC 20545

J. E. Dieckhoner

DOE Nuclear Waste Management Programs

NEW, B-107, HQ

Washington, DC 20545

C. H. George

DOE Nuclear Waste Management Programs

NEW, B-107, HQ

Washington, DC 20545

C. A. Heath

DOE Nuclear Waste Management Programs

NEW, B-107, HQ

Washington, DC 20545

M. L. Lawrence

DOE Nuclear Waste Management Programs

NEW, B-107, HQ

Washington, DC 20545 
No. of

Copies

D. J. McGoff

DOE Nuclear Waste Management Programs

NEW, B-107, HQ

Washington, DC 20545

S. Meyers/R. Romatowski

DOE Nuclear Waste Management Programs

NEW, B-107, HQ

Washington, DC 20545

G. Oerte1

DOE Nuclear Waste Management

Programs

NEW, B-107, HQ

Washington, DC 20545

A. F. Perge

DOE Nuclear Waste Management Programs

NEW, B-107, HQ

Washington, DC 20545

R. W. Ramsey, Jr.

DOE Nuclear Waste Management Programs

NEW, B-107, HQ

Washington, DC 20545

D. L. Vieth

DOE Nuclear Waste Management Programs

NEW, B-107, HQ

Washington, DC 20545

R. D. Walton

DOE Nuclear Waste Management Programs

NEW, B-107, HQ

Washington, DC 20545

S. W. Ahrends

DOE Oak Ridge Operations Office P. 0. Box E

Oak Ridge, TN 37830
No. of

Copies

D. Large

DOE Oak Ridge Operations Office

P. 0. Box E

Oak Ridge, TN 37830

S. G. Harbinson

DOE San Francisco Operations Office

1333 Broadway

Oakl and, CA 94612

E. S. Goldberg

DOE Savannah River Operations Office

P. 0. Box A

Aiken, SC 29801

W. B. Wilson

DOE Savannah River Operations Office

P. 0. Box A

Aiken, SC 29801

R. P. Whitfield

DOE Savannah River Operations Office

P. 0. Box A

Aiken, SC 29801

Los Alamos Scientific Laboratory

P. 0. Box 1663

Los Alamos NM 87544

J. B. Martin

Division of Waste Management

Nuclear Regulatory Commission

Washington, DC 20555

D. M. Rohrer

Division of Waste Management

Nuclear Regulatory Commission

Washington, DC 20555

R. Dale Smith

Division of Waste Management Nuclear Regulatory Commission Washington, DC 20555 
No. of

Copies

R. E. Cunningham

Office of Nuclear Safety

Materials and Safeguards

Nuclear Regulatory Commission

Room 562, 7915 Eastern Avenue

Silver Springs, MD 20910

27 DOE Technical Information Center

J. A. Buckham

Allied-General Nuclear Services

P. 0. Box 847

Barnwell, SC 29812

A. Williams

Allied-General Nuclear Services

P. 0. Box 847

Barnwe 11, SC 29812

J. W. Bartlett

The Analytical Sciences Corp.

6 Jacob Way

Reading, MA 01867

J. H. Kittel

Argonne National Laboratory

Office of Waste Management

Programs

9700 South Cass Avenue

Argonne, IL 60439

M. J. Steindler/L. E. Trevorrow Argonne National Laboratory

9700 South Cass Avenue

Argonne, IL 60439

A. Brandstetter

Battelle Memorial Institute

Office of Nuclear Waste I sol ation

505 King Avenue

Columbus, $\mathrm{OH} 43201$
No. of

Copies

W. Carbiener

Battelle Memorial Institute

Office of Nuclear Waste

Isolation

505 King Avenue

Columbus, $\mathrm{OH} 43201$

N. E. Carter

Battelle Memorial Institute Office of Nuclear Waste

Isolation

505 King Avenue

Columbus, $\mathrm{OH} 43201$

P. L. Hofmann

Battelle Memorial Institute

Office of Nuclear Waste

Isolation

$505 \mathrm{King}$ Avenue

Columbus, $\mathrm{OH} 43201$

M. Kehnemuyi

Battelle Memorial Institute

Office of Nuclear Waste Isolation

505 King Avenue

Columbus, $\mathrm{OH} 43201$

Beverly Rawles

Battelle Memorial Institute

Office of Nuclear Waste

Isolation

$505 \mathrm{King}$ Avenue

Columbus, $\mathrm{OH} 43201$

R. Maher, Program Manager

Waste Management Programs

Savannah River Plant

E. I. Du Pont de Nemours \& Co.

Aiken, SC 29801

W. H. Baker

E. I. Du Pont de Nemours \& Co.

Savannah River Laboratory

Aiken, SC 29801 
No. of

Copies

J. L. Crandall

E. I. Du Pont de Nemours \& Co.

Savannah River Laboratory

Aiken, SC 29801

R. G. Garvin

E. I. Du Pont de Nemours \& Co.

Savannah River Laboratory

Aiken, SC 29801

L. W. Meyer

E. I. Du Pont de Nemours \& Co. Savannah River Laboratory

Aiken, SC 29801

S. Mirshak

E. I. Du Pont de Nemours \& Co.

Savannah River Laboratory

Aiken, SC 29801

J. A. Porter

E. I. Du Pont de Nemours \& Co.

Savannah River Laboratory

Aiken, SC 29801

G. B. Levin

EG \& G Idaho

P. 0. Box 1625

Idaho Falls, ID 83415

R. Williams

Electric Power Research

Institute

3412 Hillview Avenue

P. 0. Box 10412

Palo Alto, CA 94304

J. L. Larocca, Chairman

Engineering Research and Development Authority

Empire State Plaza

Albany, NY 12223
No. of

Copies

Environmental Protection Agency

Technological Assessment

Division (AW-559)

Office of Radiation Programs

U.S. Environmental Protection Agency

Washington, DC 20460

D. M. Rosenbaum

Office of Radiation Programs

U.S. Environmental Protection Agency

1921 Jefferson Davis Highway

Arlington, VA 22202

R. A. Brown

Exxon Nuclear Idaho

P. 0. Box 2800

Idaho Falls, ID 83401

G. L. Ritter

Exxon Nuclear Idaho

P. 0. Box 2800

Idaho Falls, ID 83401

File Copy

Exxon Nuclear Idaho

P. 0. Box 2800

Idaho Falls, ID 83401

G. E. Benedict

General Atomics Co.

P. 0. Box 81608

San Diego, CA 92138

L. H. Brooks

Gulf Energy and Environmental Systems

P. 0. Box 81608

San Diego, CA 92138

J. Campbel1

Lawrence Livermore Laboratory

P. 0. Box 808

Livermore, CA 94550 
No. of

Copies

R. Roy

202 Materials Research Laboratory

Pennsylvania State University

University Park, PA 16802

C. J. Kershner

Monsanto Research Corporation

Mound Laboratory

P. 0. Box 32

Miamisburg, $\mathrm{OH} 45342$

J. P. Duckworth

Plant Manager

Nuclear Fuels Services, Inc.

P. 0. Box 124

West Valley, NY 14171

R. E. Blanco

Oak Ridge National Laboratory

P. 0. Box $Y$

Oak Ridge, TN 37830

J. 0. Blomeke

Oak Ridge National Laboratory

P. 0. Box $Y$

Oak Ridge, TN 37830

D. E. Ferguson

Oak Ridge National Laboratory

P. 0. Box $Y$

Oak Ridge, TN 37830

A. L. Lotts

Oak Ridge National Laboratory P. 0 . Box $X$

Oak Ridge, TN 37830

R. S. Lowrie

Oak Ridge National Laboratory

P. 0. Box $Y$

Oak Ridge, TN 37830

A. B. Martin

Rockwell International

8900 DeSoto Avenue

Canoga Park, CA 91304
No. of

Copies

H. Recht

Dept. 737-710

Atomics International Division

Rockwell International

Box 309

Canoga Park, CA 91304

W. S. Bennett

Rockwe 11 International

Rocky Flats Plant

P. 0. Box 464

Golden, CO 80401

E. Vejvoda

Rockwe 11 International

Rocky Flats Plant

P. 0. Box 464

Golden, CO 80401

D. R. Anderson

Sandia Laboratories

Albuquerque, NM 87185

0 . E. Jones

Sandia Laboratories

Albuquerque, NM 87185

R. G. Kepler

Sandia Laboratories

Albuquerque, NM 87185

W. Weart

Sandia Laboratories

Albuquerque, NM 87185

D. E. Harrison

Westinghouse Electric Corp.

P. 0. Box 10864

Pittsburgh, PA 15236

P. Macedo

Vitreous State Laboratory

Catholic University of America Washington, DC 20064 
No. of

Copies

R. G. Post

College of Engineering

University of Arizona

Tucson, AZ 85721

L. L. Hench

Dept. of Materials Science and Engineering

University of Florida

Gainesville, FL 32611

Dr. Hayne Palmour III

2140 Burlington Engineering Laboratories

North Carolina State University

Raleigh, NC 27607

F. K. Pittman

3508 Sagecrest Terrace

Ft. Worth, TX 76109

\section{ONSITE}

4 DOE Richland Operations Office

P. A. Craig (2)

R. E. Gerton

H. E. Ransom

11 Rockwe 11 Hanford Operations

H. Babad

L. C. Brown

R. A. Deju

R. J. Gimera

D. R. Gustavson

E. J. Kosiancic

C. M. Manry

I. E. Reep

J. H. Roecker

D. D. Wodrich

File Copy

UNC United Nuclear Industries

F. H. Bouse
No. of

Copies

2 Westinghouse Hanford Company

A. G. Blasewitz

G. L. Richardson

83 Pacific Northwest Laboratory

S. M. Barnes

W. J. Bjorklund

H. T. Blair

W. F. Bonner

D. J. Bradley

A. Brandstetter

R. A. Brouns

J. L. Buelt

R. L. Bunne 11

D. B. Cearlock

L. A. Chick

T. D. Chikalla

M. O. Cloninger

E. L. Courtright

R. D. Dierks

J. W. Finnigan

W. J. Gray

C. R. Hann

M. S. Hanson

A. J. Haverfield

O. F. Hill

L. K. Holton

J. H. Jarrett

W. S. Kelly

R. S. Kemper

D. E. Knowlton

C. A. Knox

W. L. Kuhn

L. T. Lakey

D. E. Larson

J. M. Latkovich

R. 0. Lokken

G. B. Long (3)

R. P. Marsha 11

S. A. McCullough

J. L. McElroy

G. B. Mellinger 
No. of

Copies

Pac if ic Northwest Laboratory (contd)

J. E. Mende 1

F. A. Miller

R. D. Nelson

R. G. Nelson (5)

J. F. Nesbitt (5)

R. E. Nightingale

D. E. Olesen

K. H. Oma

C. R. Palmer

P. J. Pelto

A. M. Platt

D. L. Prezbindowski (2)

F. P. Roberts

W. A. Ross

J. M. Rusin

D. H. Siemens

S. C. Slate (5)

R. L. Treat

R. P. Turcotte

H. H. Van Tuyl

B. E. Vaughan

J. W. Wald/W. E. Weber

J. H. Westsik, Jr.

L. D. Williams

Technical Information (5)

Publishing Coordination EI (2) 
4

. 